\title{
Synthesis and Antibacterial Activity of 1-(2-Fluorovinyl)-7-substituted-4-quinolone-3-carboxylic Acid Derivatives, Conformationally Restricted Analogues of Fleroxacin
}

\author{
Yoshikazu Asahina,* Kazuhiko Iwase, Fujio Iinuma, Masaki Hosaka, and Takayoshi Ishizaki \\ Discovery Research Laboratories, Kyorin Pharmaceutical Co. Ltd., 2399-1, Nogi, Nogi-Machi, \\ Shimotsuga-Gun, Tochigi, 329-0114, Japan
}

Received November 24, 2004

The novel 1-(2-fluorovinyl)-4-quinolone-3-carboxylic acid derivatives $Z$-15a-c, $E$-15a-c, $Z$-16a$\mathbf{c}$, and $E-\mathbf{1 6 a}-\mathbf{c}$, conformationally restricted analogues of fleroxacin $(\mathbf{5})$, were synthesized, and their in vitro antibacterial activity was evaluated. A dehydrosulfenylation of a 2-fluoro-2-[(4methoxyphenyl)sulfinyl]ethyl group was employed as a key step for the construction of a 2 -fluorovinyl group at the $\mathrm{N}-1$ position. It appeared evident that the $Z$-isomers $Z$-15a-c and $Z$-16a-c exhibited 2- to 32-fold more potent in vitro antibacterial activity than the corresponding $E$-isomers $E$-15a-c and $E$-16a-c. Furthermore, since $Z$-15b showed in vitro antibacterial activity and DNA gyrase inhibition comparable to that of $\mathbf{5}$, it was hypothesized that the conformation of $Z \mathbf{- 1 5 b}$ would be equivalent to the active conformer of $\mathbf{5}$. The results revealed that the antibacterial $Z$-1-(2-fluorovinyl)quinolone derivatives carry the novel N-1 substituent of the fluoroquinolones.

\section{Introduction}

Since the development of norfloxacin $(\mathbf{1}),{ }^{1}$ the first new quinolone (fluoroquinolone) in which a fluorine atom is attached at the C-6 position, other fluoroquinolones (e.g., ciprofloxacin $(\mathbf{2})^{2}$ and levofloxacin $\left.(\mathbf{3})\right)^{3}$ have been developed and clinically used for the treatment of various infectious diseases. A number of syntheses of fluoroquinolone analogues have been reported, together with the corresponding structure-activity relationship (SAR) studies. ${ }^{4}$ It is of particular note that the $\mathrm{N}-1$ substituent of fluoroquinolones plays an important role in the antibacterial activity of the fluoroquinolones, and alkyl groups such as ethyl, vinyl, cyclopropyl, and tert-butyl groups have been regarded as suitable N-1 substituents. In addition, the stereochemistry of the N-1 substituent of fluoroquinolones is also known to be important for the antibacterial activity of the fluoroquinolones, as is their bulkiness. For example, in the case of $\mathbf{3}$, which possesses a rigid $\mathrm{N}-1$ structure restricted by a 1,8-annulated ring system, the $3 S$ enantiomer of 3 was revealed as having 8-128 times more potent activity than the $3 R$-enantiomer of $3 .^{3}$ Even in the case of 1-(2-fluorocyclopropyl)quinolone derivative 4 , the conformation of the $\mathrm{N}-1$ substituent possessing a fluorine atom is restricted by a cyclopropane ring. It has been reported that the cis isomer exhibited more potent antibacterial activity than the trans isomer (Figure 1). ${ }^{5}$

These results indicated that the antibacterial potency of fluoroquinolone would be optimized by restricting the conformation of the $\mathrm{N}-1$ substituent within narrow limits. Thus, for the present study, we focused on the 2-fluoroethyl group, the N-1 substituent of fleroxacin $(5)^{6}$ (Figure 2). We designed and synthesized 1-(2fluorovinyl)quinolone derivatives $\mathbf{1 5}$ and $\mathbf{1 6}$ (Figure 2),

* To whom correspondence should be addressed. Phone: $81(0) 280$ 56 2201. Fax: $81(0) 28057$ 1293. E-mail: yoshikazu.asahina@ mb.kyorin-pharm.co.jp.
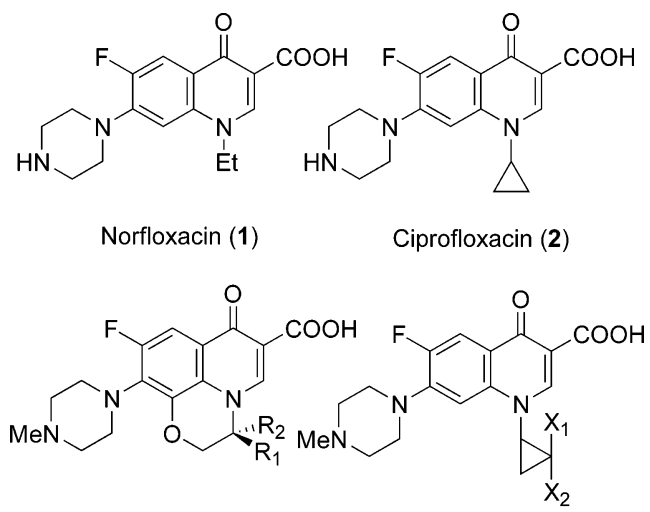

$3 S$-form (3): $\mathrm{R}_{1}=\mathrm{Me}, \mathrm{R}_{2}=\mathrm{H}$ $3 R$-form : $\mathrm{R}_{1}=\mathrm{H}, \mathrm{R}_{2}=\mathrm{Me}$

cis-form (4): $\mathrm{X}_{1}=\mathrm{F}, \mathrm{X}_{2}=\mathrm{H}$ trans-form: $\mathrm{X}_{1}=\mathrm{H}, \mathrm{X}_{2}=\mathrm{F}$

Figure 1.

both bearing a 2-fluorovinyl group and the conformation of which is restricted by the introduction of a double bond into a 2-fluoroethyl group of $\mathbf{5}$. The $Z$-isomers $Z-15 \mathbf{a}-\mathbf{c}$ and $Z-16 \mathbf{a}-\mathbf{c}$ appeared to exhibit a 2 - to 32 fold more potent in vitro antibacterial activity than the corresponding $E$-isomers $E$-15a-c and $E$-16a-c. It was also found that $Z \mathbf{- 1 5} \mathbf{b}$, structurally related to $\mathbf{5}$, showed comparable activity and DNA gyrase inhibition to that of 5; thus, it is possible that the conformation of $Z \mathbf{Z} \mathbf{- 1 5} \mathbf{b}$ is in fact equivalent to the active conformer of $\mathbf{5}$.

In this paper, we present the synthesis and in vitro antibacterial activity of the fluoroquinolone derivatives $\mathbf{1 5}$ and $\mathbf{1 6}$ carrying a $Z$ - or $E$-(2-fluorovinyl) group as novel $\mathrm{N}-1$ substituents.

\section{Results and Discussion}

Chemistry. The synthetic strategy of the 1-(2-fluorovinyl)-7-substituted-4-quinolone-3-carboxylic acid (15, 16) is given in Scheme 1. We employed a dehydrosulfenylation of 12, carrying a 2-fluoro-2-[(4-methoxy- 


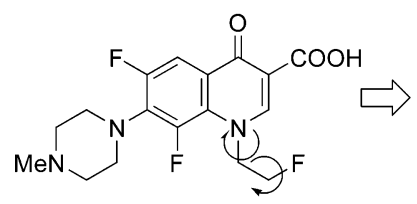

Fleroxacin (5)

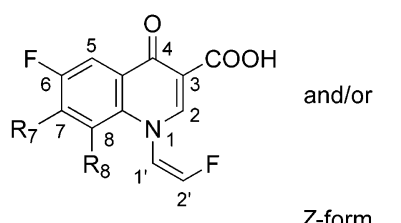<smiles></smiles><smiles>[R]c1c(F)cc2c(=O)c(C(=O)O)cn(/C=C/F)c2c1[R]</smiles>

Z-form

and/or<smiles>[R]c1c(F)cc2c(=O)c(C(=O)O)cn(/C=C/F)c2c1[R]</smiles>

$E$-form

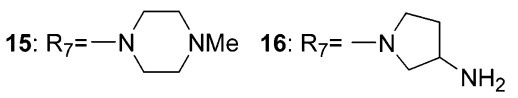

1-(2-fluorovinyl) derivatives $(15,16)$

Figure 2.

\section{Scheme 1}

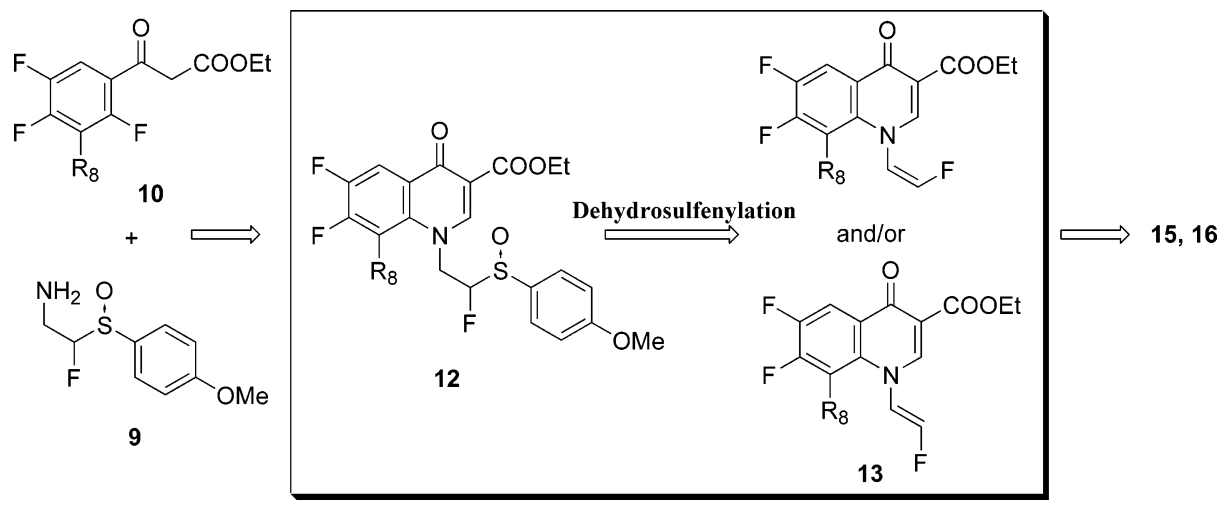

\section{Scheme $2^{a}$}<smiles>COc1ccc([SH](O)CCN2C(=O)c3ccccc3C2=O)cc1</smiles><smiles>COc1ccc([Si](C)(O)C(F)(F)CN)cc1</smiles>

8

9a

$9 b$

${ }^{a}$ Reagents: (a) DAST, $\mathrm{SbCl}_{3}, \mathrm{CH}_{2} \mathrm{Cl}_{2}$ (91\%); (b) $\mathrm{MCPBA}, \mathrm{CHCl}_{3}(90 \%)$; (c) $\mathrm{H}_{2} \mathrm{NNH}_{2} \cdot \mathrm{H}_{2} \mathrm{O}(\mathbf{9 a}, 74 \%$; 9b, 22\%).

phenyl)sulfinyl]ethyl group ${ }^{7}$ of 12 as a key step in the construction of the 2-fluorovinyl group at the $\mathrm{N}-1$ position.

The synthesis of 2-fluoro-2-[(4-methoxyphenyl)sulfinyl]ethylamine (9), used as the starting material, was achieved by hydrazinolysis of the known sulfoxide $\mathbf{8}, 8$ which was provided from $\mathbf{6}$ according to slightly modified previously reported procedures. ${ }^{9}$ After the treatment of $\mathbf{8}$ with hydrazine monohydrate, separation of the diastereomers of $\mathbf{9}$ by column chromatography gave anti isomer 9a and syn isomer $\mathbf{9 b}$. The ratio of $\mathbf{9 a}$ to $\mathbf{9 b}$ was approximately 7:2. The stereochemistry of 9a and 9b was determined by comparison of $\mathbf{9 a}$ and $9 \mathbf{b}$ as regards the chemical shifts of the $\mathrm{C}_{1}$ hydrogen atom in ${ }^{1} \mathrm{H}$ NMR and the $\mathrm{C}_{1}$ carbon atom in ${ }^{13} \mathrm{C}$ NMR. These studies were performed on the basis of the reported results for 1-(phenylsulfenyl)-1-fluoroethane. ${ }^{10}$ The major anti isomer 9a was used as the starting material to synthesize 12, which bears a 2-fluoro-2-[(4-methoxyphenyl)sulfinyl]ethyl group at the N-1 position (Scheme 2).

The synthetic route of 6,7-difluoro-1-(2-fluorovinyl)8-substituted-4-quinolones $\mathbf{1 3 a - c}$ is shown in Scheme 3 . Treatment of benzoyl acetates $\mathbf{1 0 a}-\mathbf{c}^{11}$ with dimethylformamide dimethylacetal ${ }^{12}$ followed by reaction with 9a gave enaminoesters $11 \mathbf{a}-\mathbf{c}$, respectively. Cyclization of $11 \mathbf{a}-\mathbf{c}$ under basic conditions afforded the 1-[2-fluoro2-(4-methoxyphenyl)sulfinyl]ethyl-4-quinolone derivatives $12 \mathbf{a}-\mathbf{c}$. Thermal elimination of 4-methoxybenzensulfinic acid from $\mathbf{1 2 a}-\mathbf{c}$ in xylene gave the desired 6,7- 


\section{Scheme $3^{a}$}

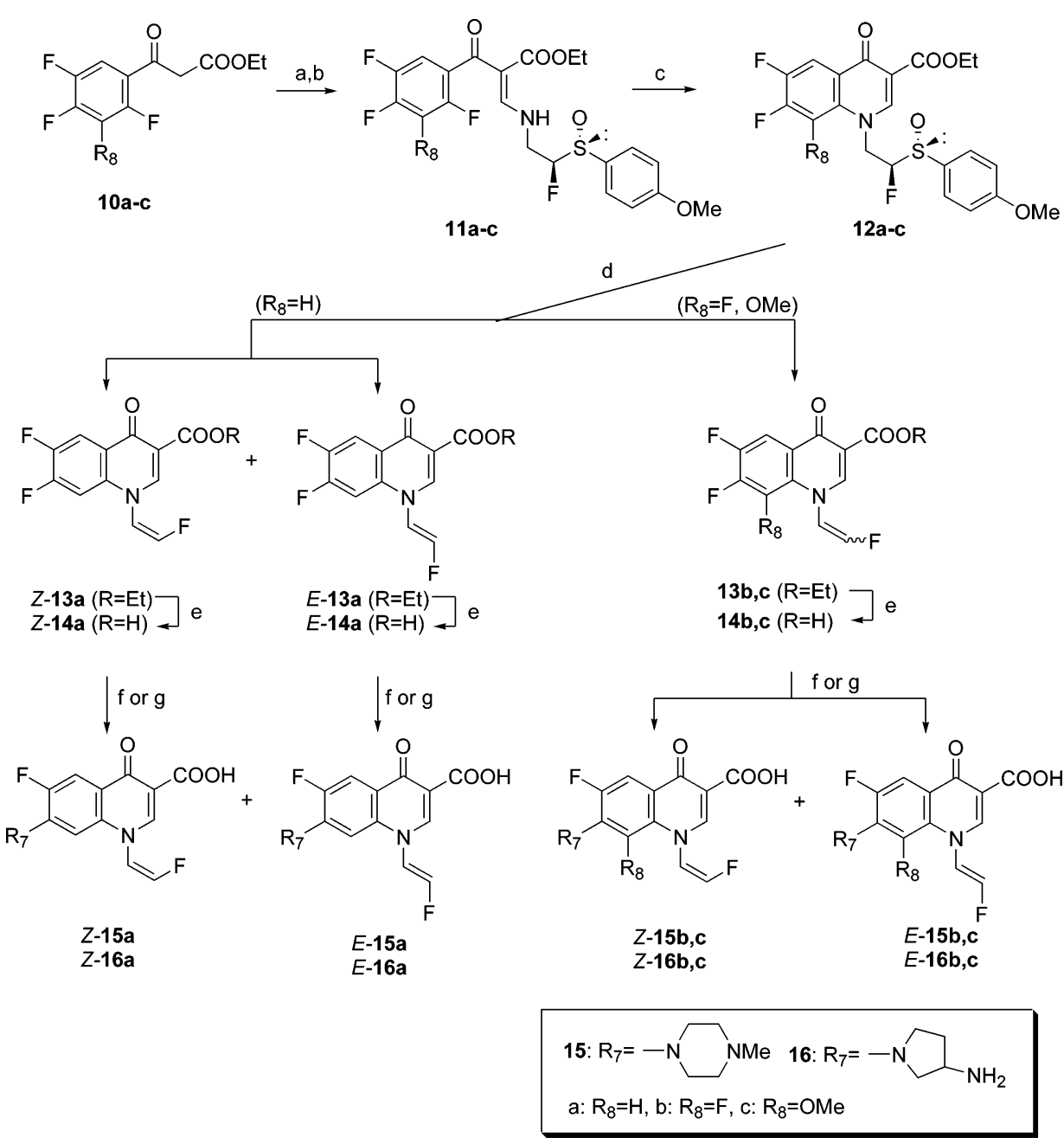

${ }^{a}$ Reagents and conditions: (a) $\mathrm{Me}_{2} \mathrm{NCH}(\mathrm{OMe})_{2}$; (b) 9a, EtOH; (c) $\mathrm{K}_{2} \mathrm{CO}_{3}$, DMF or NaH, THF; (d) reflux in xylene; (e) $\mathrm{H}_{2} \mathrm{SO}$, $\mathrm{AcOH}$, $\mathrm{H}_{2} \mathrm{O}$; (f) 1-methylpiperazine, DMSO; (g) (i) 3-tert-butoxycarbonylaminopyrrolidine, DBU, MeCN; (ii) $\mathrm{HCl}$.
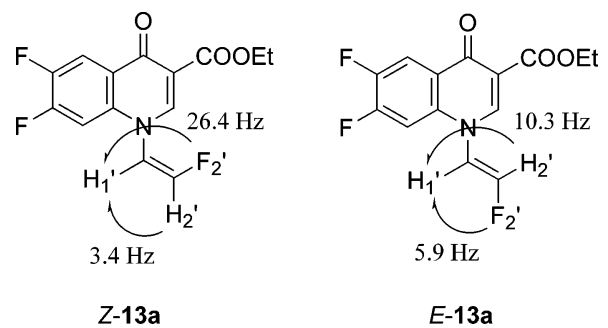

Figure 3.

difluoro-1-(2-fluorovinyl)-8-substituted-4-quinolones $\mathbf{1 3 a}-\mathbf{c}$ in a high yield as the mixture of geometrical isomers $Z \mathbf{- 1 3 a}-\mathbf{c}$ and $E \mathbf{- 1 3 a}-\mathbf{c}$. The ratio of the geometrical isomers $Z$ and $E$ was approximately $1: 2$, as calculated from the integration value obtained by ${ }^{1} \mathrm{H}$ NMR. The geometric isomers of 8-fluoro and 8-methoxy derivatives 13b,c were inseparable at this stage by silica gel column chromatography. On the other hand, the geometrical isomers $Z$-13a and $E$-13a of the 8-hydrogen derivative 13a were successfully separated by silica gel column chromatography. Their geometries were determined by comparison of the coupling constants between $\mathrm{H}_{1}^{\prime}$ and $\mathrm{F}_{2}^{\prime}$, as shown in Figure 3.

Hydrolysis of ester $Z$-13a under acidic conditions gave acid $Z$-14a without geometric isomerization. Reaction of $Z$-14a with 1-methylpiperazine gave the 7-(4-meth- ylpiperazinyl) derivative $Z$-15a. Reaction of $Z$-14a with 3-(tert-butoxycarbonylamino)pyrrolidine, followed by removal of a tert-butoxycarbonyl (Boc) group, gave the 7-(3-aminopyrrolidinyl) derivative $Z$-16a as its hydrochloride. The geometric isomers $E-\mathbf{1 5 a}$ and $\mathbf{- 1 6 a}$ were synthesized from $E \mathbf{- 1 3 a}$ in the same manner as described for $Z \mathbf{- 1 5 a}$ and -16a. The geometrical isomers of $\mathbf{1 3 b}$ and $13 \mathbf{c}$ were converted to the corresponding acids 14b and 14c in the same manner as described for the synthesis of $14 a$. Reaction of $14 b$ and $14 \mathrm{c}$ with 1 -methylpiperazine followed by separation of the geometric isomers gave the 7-(4-methylpiperazinyl) derivatives $Z$ and $E \mathbf{- 1 5 b}$, and $Z$ - and $E$-15c, respectively. Reaction of 14b and 14c with 3-Boc-aminopyrrolidine, separation of the geometrical isomers, and subsequent deprotection of the Boc groups furnished the 7-(3-aminopyrrolidinyl) derivatives $Z$ - and $E \mathbf{- 1 6 b}$, and $Z$ - and $E$-16c, respectively.

Antibacterial Activity. The in vitro antibacterial activity of the $Z$ - and $E$-1-(2-fluorovinyl)quinolone derivatives (15 and 16) against two Gram-positive strains (Staphylococcus aureus Smith and Streptococcus pneumoniae type III) and against two Gram-negative strains (Escherichia coli NIHJ JC-2 and Pseudomonas aeruginosa IID 1210) are shown in Table 1 along with those for 2 and 5. The $Z$-isomers $Z$-15a-c and $Z$-16a-c 
Table 1. In Vitro Antibacterial Activity of Compounds $Z$ - and $E$-15 and $Z$ - and $E$-16

\begin{tabular}{|c|c|c|c|c|}
\hline \multirow[b]{3}{*}{ compd } & \multicolumn{4}{|c|}{$\mathrm{MIC}(\mu \mathrm{g} / \mathrm{mL})$} \\
\hline & \multicolumn{2}{|c|}{ Gram-positive bacteria } & \multicolumn{2}{|c|}{ Gram-negative bacteria } \\
\hline & $\begin{array}{l}\text { S. aureus } \\
\text { Smith }\end{array}$ & $\begin{array}{c}\text { St. pneumoniae } \\
\text { type III }\end{array}$ & $\begin{array}{l}\text { E. coli } \\
\text { NIHJ JC-2 }\end{array}$ & $\begin{array}{l}\text { P. aeruginosa } \\
\text { IID1210 }\end{array}$ \\
\hline$Z$-15a & 0.20 & 3.13 & 0.025 & 1.56 \\
\hline$E-15 a$ & 3.13 & 100 & 0.20 & 6.25 \\
\hline$Z-15 b$ & 0.39 & 3.13 & 0.025 & 1.56 \\
\hline$E-15 b$ & 12.5 & $>50$ & 0.39 & 12.5 \\
\hline$Z-15 c$ & 0.39 & 3.13 & 0.025 & 3.13 \\
\hline$E-15 c$ & 6.25 & 50 & 0.20 & 25 \\
\hline$Z-16 a$ & 0.39 & 3.13 & 0.05 & 0.78 \\
\hline$E-16 a$ & 1.56 & 6.25 & 0.20 & 3.13 \\
\hline$Z-16 b$ & 0.20 & 0.78 & 0.05 & 0.39 \\
\hline$E-16 b$ & 3.13 & 12.5 & 0.20 & 1.56 \\
\hline$Z-16 \mathbf{c}$ & 0.39 & 1.56 & 0.0125 & 1.56 \\
\hline$Z-16 c$ & 6.25 & 12.5 & 0.10 & 6.25 \\
\hline 5 & 0.39 & 3.13 & 0.025 & 1.56 \\
\hline 2 & 0.20 & 0.78 & $\leq 0.0063$ & 0.20 \\
\hline
\end{tabular}

Table 2. Inhibitory Activity of Compounds of $Z$ - and $E$-15b against DNA Gyrase of $S$. aureus

\begin{tabular}{lc}
\hline compd & $\mathrm{IC}_{50}(\mu \mathrm{g} / \mathrm{mL})$ \\
\hline$Z-15 b$ & 72.2 \\
$E-\mathbf{1 5 b}$ & 664 \\
$\mathbf{5}$ & 68.5 \\
$\mathbf{2}$ & 20.1 \\
\hline
\end{tabular}

exhibited 2- to 32 -fold more potent in vitro antibacterial activity against both of the Gram-positive and both of the Gram-negative strains than did the corresponding $E$-isomers $E-\mathbf{1 5 a}-\mathbf{c}$ and $E$-16a-c. Our findings match the case of 1-(2-fluorocyclopropyl)quinolone derivatives, of which the cis isomers exhibited more potent antibacterial activity than the trans isomers. ${ }^{5}$ In addition, $Z-15 a-c$ and $Z-16 a-c$ exhibited comparable in vitro antibacterial activity to that of $\mathbf{5}$. Among the compounds tested, the 7-(3-aminopyrrolidinyl) derivative $Z-\mathbf{1 6 b}$, which bears a fluorine atom at the C-8 position, exhibited the most potent in vitro antibacterial activity of all of the compounds, and $Z-\mathbf{1 6 b}$ showed comparable in vitro antibacterial activity against $S$. aureus Smith, $S t$. pneumoniae type III, and $P$. aeruginosa IID1210 to that of 2 , with the exception of its activity against $E$. coli NIHJ JC-2.

Next, we evaluated the inhibition potencies of $Z$-15b and $E-\mathbf{1 5 b}$, which are conformationally restricted analogues of $\mathbf{5}$, and the inhibition potentials of $\mathbf{2}$ and $\mathbf{5}$ in the presence of DNA gyrase of $S$. aureus. As shown in Table 2 , the $\mathrm{IC}_{50}$ value of $Z \mathbf{- 1 5} \mathbf{b}$ was 9 -fold smaller than that of $E \mathbf{- 1 5 b}$ and was comparable to that of $\mathbf{5}$. This difference in the inhibition abilities of $Z-\mathbf{1 5 b}, E-\mathbf{1 5 b}$, and 5 reflected the differences in the in vitro antibacterial activity of those compounds against $S$. aureus Smith. The stereochemistry of the 2-fluorovinyl group, or the position of the fluorine atom of the 2-fluorovinyl group of $Z-\mathbf{1 5 a}$ and $E \mathbf{- 1 5} \mathbf{b}$, appeared to exert an influence on both in vitro antibacterial activity and inhibition of the target enzyme, DNA gyrase.

Conformation Analysis. Since $Z$-15b exhibited equal ability to inhibit the target enzyme, DNA gyrase, and also because it was revealed to have comparable in vitro antibacterial activity to that of $\mathbf{5}, Z$-15b could be regarded as an active conformer of $\mathbf{5}$. Therefore, we performed a study to determine the active conformer of 5 by defining the conformation of the 1-(2-fluorovinyl)

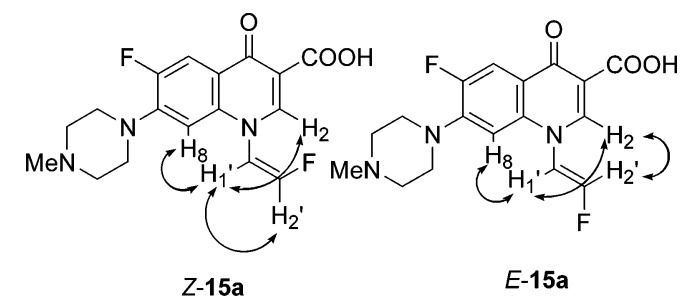

NOE: $\frown$

Figure 4. NOE experiments in ${ }^{1} \mathrm{H}$ NMR of $E$-15a and $Z$-15a.

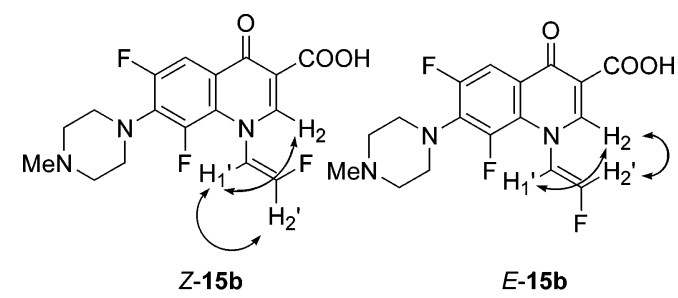

NOE: $\frown$

Figure 5. NOE experiments in ${ }^{1} \mathrm{H}$ NMR of $E$-15b and $Z$-15b.

group. First, to confirm the position of the fluorine atom on the 1-(2-fluorovinyl) group, we carried out NOE experiments using ${ }^{1} \mathrm{H}$ NMR analysis of the 8-hydrogen derivatives $Z$-15a and $E$-15a. The results are shown in Figure 4. The NOEs were observed between $\mathrm{H}_{1}{ }^{\prime}$ and both $\mathrm{H}_{2}$ and $\mathrm{H}_{8}$ for both $Z$-15a and $E$-15a. From these NOE data, it became apparent that the 2-fluorovinyl groups of $Z$-15a and $E$-15a are oriented above (or below) the plane of the quinolone ring. Furthermore, the NOE was also observed between $\mathrm{H}_{2}^{\prime}$ and $\mathrm{H}_{2}$ for $E$-15a; longrange coupling $\left({ }^{5} J=1.0 \mathrm{~Hz}\right)$ with $\mathrm{F}_{2}{ }^{\prime}$ was also observed in $\mathrm{H}_{2}$ for $Z$-15a. These ${ }^{1} \mathrm{H}$ NMR data indicated that the fluorine atoms on the 2-fluorovinyl groups of $Z$-15a and $E$-15a existed on the side opposing $\mathrm{H}_{8}$.

Additional NOE experiments were performed using the 8-fluoro derivatives $Z-\mathbf{1 5 b}$ and $E$-15b, which are conformationally restricted analogues of $\mathbf{5}$. The NOEs were observed between $\mathrm{H}_{1}{ }^{\prime}$ and $\mathrm{H}_{2}$ for both $Z$-15b and $E$-15b and between $\mathrm{H}_{2}$ 'and $\mathrm{H}_{2}$ for $E$-15b, as shown in Figure 5. In addition, long-range coupling $\left({ }^{5} J=1.5 \mathrm{~Hz}\right)$ with $\mathrm{F}_{2}{ }^{\prime}$ was observed in $\mathrm{H}_{2}$ for $Z$-15b. These ${ }^{1} \mathrm{H}$ NMR results of $Z-\mathbf{1 5 b}$ and $E-\mathbf{1 5} \mathbf{a}$ were similar to those of the corresponding 8-hydrogen derivatives $Z-\mathbf{1 5 a}$ and $E$-15a. It was therefore indicated that the 2-fluorovinyl groups of $Z-15 b$ and $E-\mathbf{1 5 b}$ have conformations similar to those of $Z-15 \mathbf{a}$ and $E-\mathbf{1 5 a}$, respectively.

To define the active conformer of $\mathbf{5}$, we then carried out the molecular modeling of the 2-fluorovinyl group of $Z$-15b. The dihedral angle of $\mathrm{C}_{2}-\mathrm{N}_{1}-\mathrm{C}_{1}{ }^{\prime}-\mathrm{C}_{2}{ }^{\prime}$ (denoted as $\Theta$ in this paper) of $Z \mathbf{- 1 5 b}$ and that of $\mathbf{5}$ changed from $-180^{\circ}$ to $180^{\circ}$ by increments of $5^{\circ}$, and the energy of each conformer was calculated by using AM1 parameters. The results are given in Figure 6. In the case of $Z-15 b$, it appeared that the two energy minima conformers existed. One of these conformers was energy minimum conformer located above the plane of the quinolone ring and was on the opposite side of a $\mathrm{C}_{8}$ fluorine atom $\left(\Theta=45^{\circ}\right.$, conformer $\left.\mathrm{A}\right)$, and the other was located under the plane of the quinolone ring $\left(\Theta=-45^{\circ}\right.$, conformer B). There was very little energy difference $(0.195 \mathrm{kcal} / \mathrm{mol})$ between the two. These results were in good agreement with the results of the ${ }^{1} \mathrm{H}$ NMR experiments with $Z \mathbf{- 1 5 b}$. In contrast, in the case of $\mathbf{5}$, 


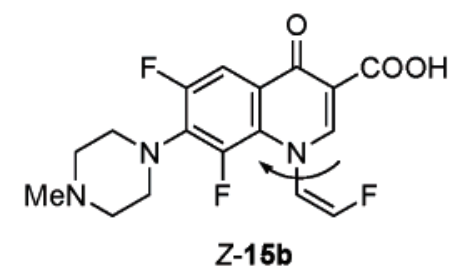<smiles>CCn1cc(C(=O)O)c(=O)c2cc(F)c(N3CCN(C)CC3)c(F)c21</smiles>
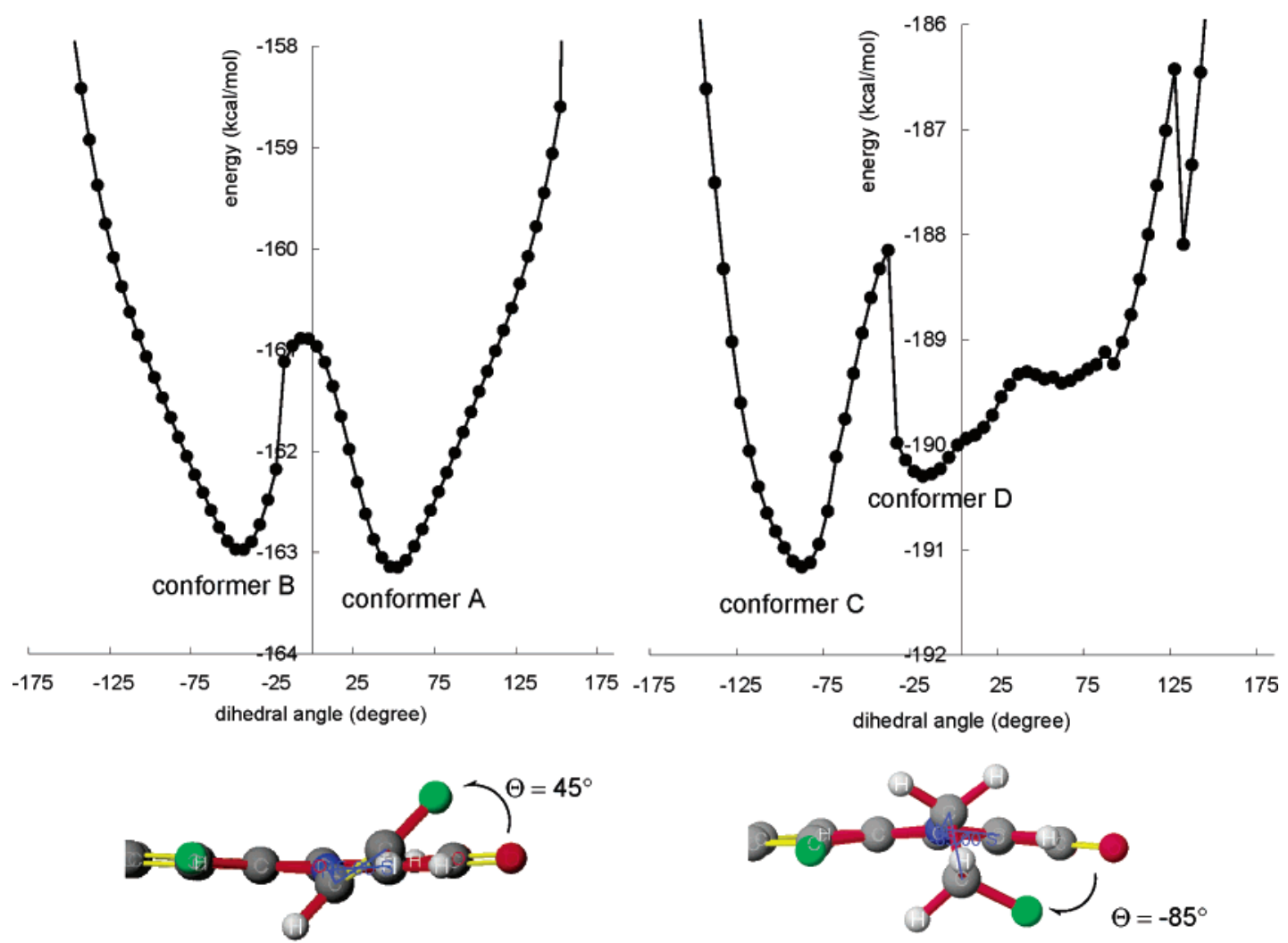

conformer A

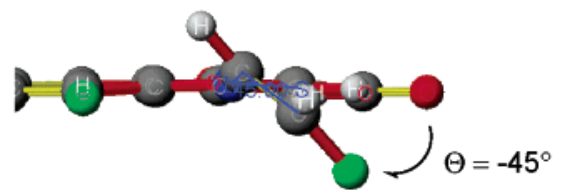

conformer B

conformer C

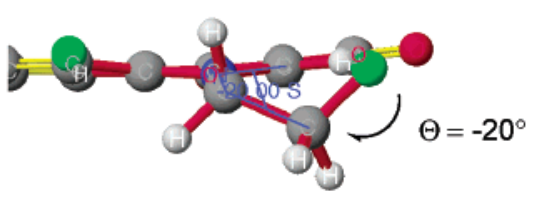

conformer D

Figure 6. Rotational energy map of $\mathrm{N}_{1}-\mathrm{R}_{1}$ bond and energy minima conformers of 1-(2-fluorovinyl) derivatives of $Z$-15b and $\mathbf{5}$ calculated by using AM1 parameters. $\Theta$ is defined as the $\mathrm{C}_{2}-\mathrm{N}_{1}-\mathrm{C}_{1}^{\prime}-\mathrm{C}_{2}^{\prime}$ dihedral angle.

although there existed the one energy minimum conformer and it was located under the plane of the quinolone ring $\left(\Theta=-85^{\circ}\right.$, conformer $\left.\mathrm{C}\right)$, there was no energy minimum conformer above the plane of the quinolone ring. These calculation results showed that the conformation of the 2-fluorovinyl group of $Z$-15b is more restricted than that of the 2-fluoroethyl group of $\mathbf{5}$, especially within the range of the upper side of the quinolone ring. Furthermore, according to a previous study, which focused on the relationship between the dihedral angle $\Theta$ of $\mathrm{N} 1$ substituents of fluoroquinolone derivatives using molecular orbital calculation and the in vitro antibacterial activity of this group, it appeared that the active conformer of the $\mathrm{N}_{1}$ substituents of the fluoroquinolones was located above the plane of the quinolone ring. ${ }^{13}$ Consequently, conformer $\mathrm{A}$ of $Z$-15b could be regarded as the active conformer of $Z \mathbf{- 1 5 b}$.

On the basis of the results of the conformation analysis of the 2-fluorovinyl group of $Z \mathbf{- 1 5} \mathbf{b}$ as described above, it is likely that conformer A would be equivalent to the active conformer of $\mathbf{5}$.

\section{Conclusions}

As described above, we succeeded in the design, synthesis, and evaluation of in vitro antibacterial activity on the 4-quinolone-3-carboxylic acids $Z-\mathbf{1 5 a}-\mathbf{c}$, $E-15 \mathbf{a}-\mathbf{c}, Z-16 \mathbf{a}-\mathbf{c}$, and $E-16 \mathbf{a}-\mathbf{c}$, which are conformationally restricted analogues of $\mathbf{5}$ carrying a 2-fluoroethyl group as the novel N-1 substituent. The synthesis of these compounds was achieved in five steps from $\mathbf{1 0 a}-\mathbf{c}$ by a method featuring a dehydrosulfenylation of the 2-fluoro-2-[(4-methoxyphenyl)sulfinyl]ethyl group as the key step for the construction of the 2-fluorovinyl group at the $\mathrm{N}-1$ position. It appeared evident that the $Z$-isomers $Z$-15a-c and $Z$-16a-c exhibited 2- to 32 -fold more potent in vitro antibacterial activity than the corresponding $E$-isomers $E$-15a-c and $E$-16a-c. On the basis of the in vitro antibacterial activity analysis, as 
well as analysis of the DNA gyrase inhibitory ability of $Z$-15b and 5, and the conformation analysis of $Z-15 \mathbf{b}$, it can be concluded that the conformation of $Z-\mathbf{1 5 b}$ is most likely equivalent to the active conformer of $\mathbf{5}$. Considering the results of the present study, the novel $Z$-1-(2-fluorovinyl)-4-quinolone-3-carboxylic acid would be an intriguing scaffold for the exploration of novel quinolone antibacterials. Further investigation of the $Z$-(1-fluorovinyl)quinolones is in progress.

\section{Experimental Section}

Melting points were determined with a Yanagimoto micromelting point apparatus and are uncorrected. Elemental analyses are within $\pm 0.4 \%$ of the theoretical values and were determined by a Yanaco CHN MT-5 instrument. Infrared spectra (IR) were recorded with a JASCO FTIR-5300 spectrometer. Measurements of mass spectra (MS) and highresolution MS (HRMS) were performed with a JEOL JMS SX102A mass spectrometer. Proton nuclear magnetic resonance $\left({ }^{1} \mathrm{H}\right.$ NMR) were measured with a JEOL EX-90 $(90 \mathrm{MHz})$ or a JEOL JMN-EX400 (400 MHz) spectrometer. The chemical shifts are expressed in parts per million ( $\delta$ value) downfield from tetramethylsilane, using tetramethylsilane $(\delta=0)$ and/ or residual solvents such as chloroform $(\delta=7.26)$ as an internal standard. Splitting patterns are indicated as follows: $\mathrm{s}$, singlet; d, doublet; t, triplet; $\mathrm{q}$, quartet; m, multiplet; br, broad peak. Column chromatography was carried out with silica gel [silica gel 60 (Kanto)] as an absorbent. Merck precoated thin-layer chromatography (TLC) plates (silica gel $60 \mathrm{~F}_{254}, 0.25 \mathrm{~mm}$, Art 5715) were used for the TLC analysis. Solutions were dried over sodium sulfate, and the solvent was removed by rotary evaporation under reduced pressure.

$\boldsymbol{N}$-[2-[2-Fluoro-(4-methoxyphenyl)thio]ethyl]phthalimide (7). Diethylaminosulfur trifluoride $(4.21 \mathrm{~mL}, 31.9 \mathrm{mmol})$ was added to a solution of $N$-[2-[(4-methoxyphenyl)sulfinyl]ethyl]phthalimide $(6,6.00 \mathrm{~g}, 18.2 \mathrm{mmol})$ and antiomonyl(III) chloride (125 mg, $0.548 \mathrm{mmol}$ ) in anhydrous $\mathrm{CH}_{2} \mathrm{Cl}_{2}(42 \mathrm{~mL})$ under ice cooling, and the mixture was stirred at room temperature for $3 \mathrm{~h}$. After the reaction was quenched by adding saturated aqueous $\mathrm{NaHCO}_{3}$ solution $(36 \mathrm{~mL})$ under ice cooling, the mixture was extracted with $\mathrm{CH}_{2} \mathrm{Cl}_{2}(50 \mathrm{~mL})$. The combined $\mathrm{CH}_{2} \mathrm{Cl}_{2}$ extracts were washed with water $(2 \times 30$ $\mathrm{mL}$ ), dried over anhydrous $\mathrm{Na}_{2} \mathrm{SO}_{4}$, filtered, and then concentrated in vacuo to give $\mathbf{7}(5.52 \mathrm{~g}, 91 \%)$ as pale-brown crystals. ${ }^{1} \mathrm{H} \mathrm{NMR}\left(\mathrm{CDCl}_{3}\right) \delta: 3.82\left(\mathrm{~s}, 3 \mathrm{H}, \mathrm{CH}_{3}\right), 4.04$ (ddd, $J=40.2$, $14.4,4.9 \mathrm{~Hz}, 1 \mathrm{H}, \mathrm{CH}_{2}$ ), 4.08 (ddd, $J=42.0,14.2,8.1 \mathrm{~Hz}, 1 \mathrm{H}$, $\mathrm{CH}_{2}$ ), 5.94 (ddd, $\left.J=53.6,8.1,4.9 \mathrm{~Hz}, 1 \mathrm{H}, \mathrm{CH}\right), 6.87-6.90(\mathrm{~m}$, $2 \mathrm{H}, \mathrm{Ar}-\mathrm{H}), 7.48-7.50(\mathrm{~m}, 2 \mathrm{H}, \mathrm{Ar}-\mathrm{H}), 7.74$ (dd, $2 \mathrm{H}, \mathrm{Ar}-\mathrm{H})$, 7.87 (dd, $2 \mathrm{H}, \mathrm{Ar}-\mathrm{H})$.

$\boldsymbol{N}$-[2-Fluoro-2-[(4-methoxyphenyl)sulfinyl]ethyl]phthalimide (8). To a solution of $7(5.51 \mathrm{~g}, 16.6 \mathrm{mmol})$ in $\mathrm{CHCl}_{3}(100 \mathrm{~mL}), m$-chloroperoxybenzoic acid $(65 \%, 4.41 \mathrm{~g}, 16.6$ mmol) was added at -50 to $-40{ }^{\circ} \mathrm{C}$ for $40 \mathrm{~min}$, and the mixture was stirred at the same temperature for $20 \mathrm{~min}$. The reaction mixture was washed with saturated aqueous $\mathrm{NaHCO}_{3}$ solution $(2 \times 100 \mathrm{~mL}), 10 \%$ aqueous $\mathrm{Na}_{2} \mathrm{SO}_{3}(2 \times 100 \mathrm{~mL})$ solution and water $(100 \mathrm{~mL})$, dried over anhydrous $\mathrm{Na}_{2} \mathrm{SO}_{4}$, filtered, and then concentrated in vacuo. Flash chromatography (hexane/AcOEt $=1: 1 \rightarrow \mathrm{AcOEt})$ of the residue gave $\mathbf{8}(5.18 \mathrm{~g}, 90 \%)$ as a white solid. ${ }^{1} \mathrm{H}$ NMR $\left(\mathrm{CDCl}_{3}\right) \delta: 3.85\left(\mathrm{~s}, 2.4 \mathrm{H}, \mathrm{CH}_{3}\right), 3.86$ (s, $\left.0.6 \mathrm{H}, \mathrm{CH}_{3}\right), 4.08-4.20\left(\mathrm{~m}, 1.2 \mathrm{H}, \mathrm{CH}_{2}\right), 4.39$ (ddd, $J=14.6$, $\left.12.7,7.8 \mathrm{~Hz}, 0.8 \mathrm{H}, \mathrm{CH}_{2}\right), 5.32(\mathrm{ddd}, J=48.8,7.8,4.4 \mathrm{~Hz}, 0.8 \mathrm{H}$, $\mathrm{CH}), 5.42$ (dt, $J=49.8,5.9 \mathrm{~Hz}, 0.8 \mathrm{H}, \mathrm{CH}), 7.03-7.08(\mathrm{~m}, 2 \mathrm{H}$, $\mathrm{Ar}-\mathrm{H}), 7.65-7.68(\mathrm{~m}, 2 \mathrm{H}, \mathrm{Ar}-\mathrm{H}), 7.72-7.76(\mathrm{~m}, 2 \mathrm{H}, \mathrm{Ar}-\mathrm{H})$, 7.84-7.88 (m, 2H, Ar-H).

2-[2-Fluoro-2-(4-methoxyphenyl)sulfinyl]ethylamine (9a, 9b). Hydrazine monohydrate $(1.30 \mathrm{~mL}, 26.8 \mathrm{mmol})$ was added to a solution of 8 (4.66 g, $13.4 \mathrm{mmol})$ in $\mathrm{EtOH}(50 \mathrm{~mL})$, and the mixture was heated under reflux for $1 \mathrm{~h}$. After the mixture was cooled, the precipitates that had formed were filtered off and the filtrate was concentrated in vacuo. Flash chromatography $\left(\mathrm{CH}_{2} \mathrm{Cl}_{2} / \mathrm{MeOH}=10: 1\right)$ of the residue gave $\mathbf{9 a}(2.16 \mathrm{~g}, 74 \%)$ as a pale-brown syrup and $\mathbf{9 b}(627 \mathrm{mg}, 22 \%)$ as a red-brown oil.

9a. ${ }^{1} \mathrm{H} \mathrm{NMR}\left(\mathrm{CDCl}_{3}\right) \delta: 3.35$ (ddd, $J=22.0,15.1,3.4 \mathrm{~Hz}$, $\left.1 \mathrm{H}, \mathrm{C}_{1}-\mathrm{H}\right), 3.44\left(\mathrm{ddd}, J=27.3,15.1,4.9 \mathrm{~Hz}, 1 \mathrm{H}, \mathrm{C}_{1}-\mathrm{H}\right), 3.87$ (s, $3 \mathrm{H}, \mathrm{CH}_{3}$ ), 4.81 (ddd, $J=48.8,4.9,3.4 \mathrm{~Hz}, 1 \mathrm{H}, \mathrm{C}_{2}-\mathrm{H}$ ), $7.05-$ $7.09(\mathrm{~m}, 2 \mathrm{H}, \mathrm{Ar}-\mathrm{H}), 7.62-7.66(\mathrm{~m}, 2 \mathrm{H}, \mathrm{Ar}-\mathrm{H}) .{ }^{13} \mathrm{C} \mathrm{NMR}$ $\left(\mathrm{CDCl}_{3}\right) \delta: 40.6(J=20.2 \mathrm{~Hz}), 55.6,107.6(J=219 \mathrm{~Hz}), 115.0$ (2C), $126.9(2 \mathrm{C}), 130.9(J=4.9 \mathrm{~Hz}), 162.7 . \mathrm{MS}(\mathrm{EI}) \mathrm{m} / z: 217$ $\left(\mathrm{M}^{+}\right)$. HRMS (EI) for $\mathrm{C}_{9} \mathrm{H}_{12} \mathrm{FNO}_{2} \mathrm{~S}\left(\mathrm{M}^{+}\right)$: calcd, 217.0573; found, 217.0546 .

9b. ${ }^{1} \mathrm{H} \mathrm{NMR}\left(\mathrm{CDCl}_{3}\right) \delta$ : 3.08 (ddd, $J=17.1,14.6,6.3 \mathrm{~Hz}$, $\left.1 \mathrm{H}, \mathrm{C}_{1}-\mathrm{H}\right), 3.25\left(\mathrm{ddd}, J=22.5,14.6,4.9 \mathrm{~Hz}, 1 \mathrm{H}, \mathrm{C}_{1}-\mathrm{H}\right), 3.87$ (s, $3 \mathrm{H}, \mathrm{CH}_{3}$ ), 4.97 (ddd, $J=47.9,6.3,4.9 \mathrm{~Hz}, 1 \mathrm{H}, \mathrm{C}_{2}-\mathrm{H}$ ), 7.05$7.09(\mathrm{~m}, 2 \mathrm{H}, \mathrm{Ar}-\mathrm{H}), 7.61-7.64(\mathrm{~m}, 2 \mathrm{H}, \mathrm{Ar}-\mathrm{H}) .{ }^{13} \mathrm{C} \mathrm{NMR}$ $\left(\mathrm{CDCl}_{3}\right) \delta: 40.7(J=22.1 \mathrm{~Hz}), 55.6,106.4(J=219 \mathrm{~Hz}), 114.9$ (2C), $127.1(2 \mathrm{C}), 129.3(\mathrm{~J}=3.7 \mathrm{~Hz}), 162.7$. MS (EI) $\mathrm{m} / z: 217$ $\left(\mathrm{M}^{+}\right)$. HRMS (EI) for $\mathrm{C}_{9} \mathrm{H}_{12} \mathrm{FNO}_{2} \mathrm{~S}\left(\mathrm{M}^{+}\right)$: calcd, 217.0573; found, 217.0562 .

Ethyl 2-[2-(Fluoro-2-(4-methoxyphenylsulfinyl)ethylamino)-1-(2,4,5-trifluorobenzoyl)] acrylate (11a). To a solution of 10a $(1.03 \mathrm{~g}, 4.18 \mathrm{mmol})$ in benzene $(25 \mathrm{~mL}), N, N$ dimethylformamide dimethyl acetal $(2.50 \mathrm{~mL}, 18.8 \mathrm{mmol})$ was added. The mixture was heated under reflux for $1 \mathrm{~h}$ and then concentrated in vacuo. To a solution of the residue in toluene (12 $\mathrm{mL}), 9 \mathbf{a}(1.00 \mathrm{~g}, 4.60 \mathrm{mmol})$ was added. The mixture was stirred at room temperature for $2 \mathrm{~h}$ and then concentrated in vacuo. Flash chromatography (hexane/AcOEt $=1: 1$ ) of the residue gave $11 \mathrm{a}(1.57 \mathrm{~g}, 79 \%)$ as a yellow foam. ${ }^{1} \mathrm{H}$ NMR $\left(\mathrm{CDCl}_{3}\right) \delta: 1.40\left(\mathrm{t}, J=7.3 \mathrm{~Hz}, 3 \mathrm{H}, \mathrm{CH}_{3}\right), 3.91\left(\mathrm{~s}, 3 \mathrm{H}, \mathrm{CH}_{3}\right)$, $4.38\left(\mathrm{q}, J=7.3 \mathrm{~Hz}, 2 \mathrm{H}, \mathrm{CH}_{2}\right), 4.66-4.81\left(\mathrm{~m}, 2 \mathrm{H}, \mathrm{CH}_{2}\right), 5.15$ (ddd, $J=48.8,7.8,2.0 \mathrm{~Hz}, \mathrm{CHF}), 6.78(1 \mathrm{H}, \mathrm{dd}, J=11.0,6.3$ $\mathrm{Hz}, \mathrm{Ar}-\mathrm{H}), 7.15(\mathrm{~d}, J=8.8 \mathrm{~Hz}, 2 \mathrm{H}, \mathrm{Ar}-\mathrm{H}), 7.66(\mathrm{~d}, J=8.8$ $\mathrm{Hz}, 2 \mathrm{H}, \mathrm{Ar}-\mathrm{H}), 8.26$ (dd, $J=10.3,8.8 \mathrm{~Hz}, 1 \mathrm{H}, \mathrm{Ar}-\mathrm{H}), 8.38$ (s, 1H, CH).

Ethyl 2-[2-(Fluoro-2-(4-methoxyphenylsulfinyl)ethylamino)-1-(2,3,4,5-tetrafluorobenzoyl)]acrylate (11b). The compound 11b (1.82 g, 99\%) was prepared from $10 b(1.00 \mathrm{~g}$, $3.79 \mathrm{mmol})$ and $9 \mathbf{a}(948 \mathrm{mg}, 4.36 \mathrm{mmol})$ by the same method as that used for 11a. ${ }^{1} \mathrm{H}$ NMR $\left(\mathrm{CDCl}_{3}\right) \delta$ : 0.99 and 1.40 (each t, $J=7.3 \mathrm{~Hz}$, total $\left.3 \mathrm{H}, \mathrm{CH}_{3}\right), 3.88\left(\mathrm{~s}, 3 \mathrm{H}, \mathrm{CH}_{3}\right), 4.03-4.16(\mathrm{~m}$, $4 \mathrm{H}, \mathrm{CH}_{2} \times 2$ ), 4.93-4.95 and 5.05-5.07 (each $\mathrm{m}$, total $1 \mathrm{H}$, $\mathrm{CHF}), 6.99-7.11(\mathrm{~m}, 3 \mathrm{H}, \mathrm{Ar}-\mathrm{H}), 7.63(\mathrm{~d}, 2 \mathrm{H}, \mathrm{Ar}-\mathrm{H}), 7.99$ and 8.11 (each d, total $1 \mathrm{H}, \mathrm{CH}$ ), 9.40-9.60 and 10.8-11.0 (each br, total $1 \mathrm{H}, \mathrm{NH})$.

Ethyl 2-[2-(Fluoro-2-(4-methoxyphenylsulfinyl)ethylamino)-1-(2,4,5-trifluoro-3-methoxybenzoyl)]acrylate (11c). The compound 11c (1.62 g, 89\%) was prepared from 10c $(1.00 \mathrm{~g}, 3.62 \mathrm{mmol})$ and $\mathbf{9 a}(905 \mathrm{mg}, 4.17 \mathrm{mmol})$ by the same method as that used for 11a. ${ }^{1} \mathrm{H}$ NMR $\left(\mathrm{CDCl}_{3}\right) \delta$ : 0.98 and 1.10 (each t, $J=7.3 \mathrm{~Hz}$, total $\left.3 \mathrm{H}, \mathrm{CH}_{3}\right), 3.88\left(\mathrm{~s}, 3 \mathrm{H}, \mathrm{CH}_{3}\right)$, $4.00\left(\mathrm{~s}, 3 \mathrm{H}, \mathrm{CH}_{3}\right), 4.03-4.16\left(\mathrm{~m}, 2 \mathrm{H}, \mathrm{CH}_{2} \times 2\right), 4.91-5.07(\mathrm{~m}$, $1 \mathrm{H}, \mathrm{CHF}$ ), 6.86-6.92 and 6.98-7.04 (each $\mathrm{m}$, total $1 \mathrm{H}, \mathrm{Ar}-$ $\mathrm{H}), 7.08-7.10(\mathrm{~m}, 2 \mathrm{H}, \mathrm{Ar}-\mathrm{H}), 7.63(\mathrm{~d}, J=8.8 \mathrm{~Hz}, 2 \mathrm{H}, \mathrm{Ar}-\mathrm{H})$, $7.96(\mathrm{~d}, J=14.2 \mathrm{~Hz}, 0.3 \mathrm{H}, \mathrm{CH}), 8.08(\mathrm{~d}, J=13.7 \mathrm{~Hz}, 0.7 \mathrm{H}$, $\mathrm{CH}), 9.41-9.54$ and $10.8-10.9$ (each br, total $1 \mathrm{H}, \mathrm{NH}$ ).

Ethyl 1-[2-Fluoro-2-(4-methoxyphenylsulfinyl)ethyl]6,7-difluoro-1,4-dihydro-4-oxo-3-quinolinecarboxylate (12a). A solution of $\mathbf{1 1 a}(1.28 \mathrm{~g}, 2.70 \mathrm{mmol})$ in anhydrous THF $(13 \mathrm{~mL})$ was added to a suspension of sodium hydride $(60 \%$ oil suspension, $108 \mathrm{mg}, 2.70 \mathrm{mmol})$ in anhydrous THF (13 mL) under cooling with ice. After the reaction mixture was stirred at a constant temperature for $30 \mathrm{~min}$, it was poured into ice/ water $(30 \mathrm{~mL})$. The resulting precipitates were collected by filtration, washed with water, and then dried in vacuo to give 12a (945 mg, 77\%). Mp: $191-193{ }^{\circ} \mathrm{C}(\mathrm{MeOH}) .{ }^{1} \mathrm{H}$ NMR $\left(\mathrm{CDCl}_{3}\right) \delta: 1.40\left(\mathrm{t}, J=7.3 \mathrm{~Hz}, 3 \mathrm{H}, \mathrm{CH}_{3}\right), 3.89\left(\mathrm{~s}, 3 \mathrm{H}, \mathrm{CH}_{3}\right)$, $4.38\left(\mathrm{q}, J=7.3 \mathrm{~Hz}, 2 \mathrm{H}, \mathrm{CH}_{2}\right), 4.62(\mathrm{ddd}, J=37.6,16.6,7.8$ $\mathrm{Hz}, 1 \mathrm{H}, \mathrm{C}_{1}{ }^{\prime}-\mathrm{H}$ ), 4.75 (ddd, $J=28.3,16.1,2.0 \mathrm{~Hz}, 1 \mathrm{H}, \mathrm{C}_{1}^{\prime}-\mathrm{H}$ ), 5.15 (ddd, $\left.J=48.9,7.8,2.0 \mathrm{~Hz}, 1 \mathrm{H}, \mathrm{C}_{2}^{\prime}-\mathrm{H}\right), 6.79$ (dd, $J=$ 11.0, $\left.6.3 \mathrm{~Hz}, 1 \mathrm{H}, \mathrm{C}_{8}-\mathrm{H}\right), 7.15(\mathrm{~d}, J=8.8 \mathrm{~Hz}, 2 \mathrm{H}, \mathrm{Ar}-\mathrm{H}), 7.66$ $(\mathrm{d}, J=8.8 \mathrm{~Hz}, 2 \mathrm{H}, \mathrm{Ar}-\mathrm{H}), 8.26(\mathrm{dd}, J=10.3,8.8 \mathrm{~Hz}, 1 \mathrm{H}$, $\left.\mathrm{C}_{5}-\mathrm{H}\right), 8.38\left(\mathrm{~s}, 1 \mathrm{H}, \mathrm{C}_{2}-\mathrm{H}\right)$. IR $(\mathrm{KBr}) \mathrm{cm}^{-1}: 1732,1602 . \mathrm{MS}$ (EI) $m / z: 453\left(\mathrm{M}^{+}\right)$. Anal. $\left(\mathrm{C}_{21} \mathrm{H}_{18} \mathrm{~F}_{3} \mathrm{NO}_{5} \mathrm{~S}\right) \mathrm{C}, \mathrm{H}, \mathrm{N}$. 
Ethyl 1-[2-Fluoro-2-(4-methoxyphenylsulfinyl)ethyl]6,7,8-trifluoro-1,4-dihydro-4-oxo-3-quinolinecarboxylate (12b). The compound $\mathbf{1 2 b}(1.36 \mathrm{~g}, 80 \%)$ was prepared from $11 b(1.77 \mathrm{~g}, 3.75 \mathrm{mmol})$ by the same method as that used for 12a. Mp: $136-137^{\circ} \mathrm{C} .{ }^{1} \mathrm{H}$ NMR $\left(\mathrm{CDCl}_{3}\right) \delta: 1.40(\mathrm{t}, J=7.3$ $\mathrm{Hz}, 3 \mathrm{H}, \mathrm{CH}_{3}$ ), 3.89 (s, $3 \mathrm{H}, \mathrm{CH}_{3}$ ), 4.39 (q, $J=7.3 \mathrm{~Hz}, 2 \mathrm{H}, \mathrm{CH}_{2}$ ), $4.66-4.76\left(\mathrm{~m}, 1 \mathrm{H}, \mathrm{C}_{1}{ }^{\prime}-\mathrm{H}\right), 4.96(\mathrm{ddt}, J=27.6,16.1,2.9 \mathrm{~Hz}$, $1 \mathrm{H}, \mathrm{C}_{1}{ }^{\prime}-\mathrm{H}$ ), 5.27 (dd, $\left.J=49.3,8.3 \mathrm{~Hz}, 1 \mathrm{H}, \mathrm{C}_{2}{ }^{\prime}-\mathrm{H}\right), 7.08-7.21$ $(\mathrm{m}, 2 \mathrm{H}, \mathrm{Ar}-\mathrm{H}), 7.59-7.65(\mathrm{~m}, 2 \mathrm{H}, \mathrm{Ar}-\mathrm{H}), 8.12$ (dd, $J=9.0$, $\left.2.4 \mathrm{~Hz}, 1 \mathrm{H}, \mathrm{C}_{5}-\mathrm{H}\right), 8.37\left(\mathrm{~s}, 1 \mathrm{H}, \mathrm{C}_{2}-\mathrm{H}\right) . \mathrm{IR}(\mathrm{KBr}) \mathrm{cm}^{-1}: 1732$, 1701, 1602. MS (EI) $m / z: 471\left(\mathrm{M}^{+}\right)$. Anal. $\left(\mathrm{C}_{21} \mathrm{H}_{17} \mathrm{~F}_{4} \mathrm{NO}_{5} \mathrm{~S}\right) \mathrm{C}$, $\mathrm{H}, \mathrm{N}$.

Ethyl 1-[2-Fluoro-2-(4-methoxyphenylsulfinyl)ethyl]6,7-difluoro-1,4-dihydro-8-methoxy-4-oxo-3-quinolinecarboxylate (12c). The compound 12c (1.33 g, 88\%) was prepared from 11c $(1.57 \mathrm{~g}, 3.12 \mathrm{mmol})$ by the same method as that used for 12a. Mp: $131-136{ }^{\circ} \mathrm{C}\left(\mathrm{MeOH} / \mathrm{Et}_{2} \mathrm{O}\right) .{ }^{1} \mathrm{H}$ NMR $\left(\mathrm{CDCl}_{3}\right) \delta: 1.40\left(\mathrm{t}, J=7.3 \mathrm{~Hz} 3 \mathrm{H}, \mathrm{CH}_{3}\right), 3.82(\mathrm{~d}, J=2.4 \mathrm{~Hz}$, $\left.3 \mathrm{H}, \mathrm{OCH}_{3}\right), 3.89\left(3 \mathrm{H}, \mathrm{s}, \mathrm{OCH}_{3}\right), 4.39\left(2 \mathrm{H}, \mathrm{m}, \mathrm{CH}_{2}\right), 4.63(1 \mathrm{H}$, ddd, $\left.J=15.3,12.2,9.3 \mathrm{~Hz}, \mathrm{C}_{1}^{\prime}-\mathrm{H}\right), 5.20(1 \mathrm{H}$, ddd, $J=49.8$, 9.3, $\left.2.4 \mathrm{~Hz}, \mathrm{C}_{1}{ }^{\prime}-\mathrm{H}\right), 5.33\left(1 \mathrm{H}, \mathrm{ddd}, J=49.8,9.3,2.4 \mathrm{~Hz}, \mathrm{C}_{2}{ }^{\prime}-\right.$ $\mathrm{H}), 7.10(\mathrm{~d}, J=8.8 \mathrm{~Hz}, 2 \mathrm{H}, \mathrm{Ar}-\mathrm{H}), 7.62(\mathrm{~d}, J=8.8 \mathrm{~Hz}, 2 \mathrm{H}$, $\mathrm{Ar}-\mathrm{H}), 8.86\left(\mathrm{dd}, J=10.3,8.8 \mathrm{~Hz}, 1 \mathrm{H}, \mathrm{C}_{5}-\mathrm{H}\right), 8.32(1 \mathrm{H}, \mathrm{s}$, $\left.\mathrm{C}_{2}-\mathrm{H}\right)$. IR $(\mathrm{KBr}) \mathrm{cm}^{-1}: 1730,1618 . \mathrm{MS} \mathrm{m} / z: 483\left(\mathrm{M}^{+}\right)$. Anal. $\left(\mathrm{C}_{22} \mathrm{H}_{20} \mathrm{~F}_{3} \mathrm{NO}_{6} \mathrm{~S} \cdot 0.25 \mathrm{H}_{2} \mathrm{O}\right) \mathrm{C}, \mathrm{H}, \mathrm{N}$.

Ethyl 6,7-Difluoro-1-(2-fluorovinyl)-1,4-dihydro-4-oxo3-quinolinecarboxylate (13a). A mixture of 12a (1.05 g, 2.32 mmol) and xylene $(22 \mathrm{~mL})$ was heated under reflux for $3.5 \mathrm{~h}$ and then concentrated in vacuo. Flash chromatography $\left(\mathrm{CH}_{2^{-}}\right.$ $\left.\mathrm{Cl}_{2} / \mathrm{MeOH}=10: 1\right)$ of the residue gave $Z \mathbf{- 1 3 a}(235 \mathrm{mg}, 34 \%)$ and $E$-13a ( $427 \mathrm{mg}, 62 \%$ ) as white solids.

Z-13a. ${ }^{1} \mathrm{H}$ NMR $\left(\mathrm{CDCl}_{3}\right) \delta: 1.41\left(\mathrm{t}, J=7.3 \mathrm{~Hz}, 3 \mathrm{H}, \mathrm{CH}_{3}\right)$, $4.40\left(\mathrm{q}, J=7.3 \mathrm{~Hz}, 2 \mathrm{H}, \mathrm{COOCH}_{2}\right), 6.36(\mathrm{dd}, J=26.4,3.4 \mathrm{~Hz}$, $1 \mathrm{H}, Z-\mathrm{C}_{1}{ }^{\prime}-\mathrm{H}$ ), $7.03\left(\mathrm{dd}, J=74.7,3.4 \mathrm{~Hz}, 1 \mathrm{H}, Z-\mathrm{C}_{2}{ }^{\prime}-\mathrm{H}\right.$ ), 7.25 $\left(\mathrm{dd}, J=10.7,7.8 \mathrm{~Hz}, 1 \mathrm{H}, \mathrm{C}_{8}-\mathrm{H}\right), 8.26(\mathrm{dd}, J=10.3,8.8 \mathrm{~Hz}$ $1 \mathrm{H}, \mathrm{C}_{5}-\mathrm{H}$ ), 8.45 (d, $\left.J=1.0 \mathrm{~Hz}, 1 \mathrm{H}, \mathrm{C}_{2}-\mathrm{H}\right)$. MS (EI) $\mathrm{m} / z: 297$ $\left(\mathrm{M}^{+}\right)$. HRMS (EI) for $\mathrm{C}_{14} \mathrm{H}_{10} \mathrm{~F}_{3} \mathrm{NO}_{3}\left(\mathrm{M}^{+}\right)$: calcd, 297.0613; found, 297.0638. Anal. $\left(\mathrm{C}_{14} \mathrm{H}_{10} \mathrm{~F}_{3} \mathrm{NO}_{3}\right) \mathrm{C}, \mathrm{H}, \mathrm{N}$.

E-13a. ${ }^{1} \mathrm{H}$ NMR $\left(\mathrm{CDCl}_{3}\right) \delta: 1.40\left(\mathrm{t}, J=7.3 \mathrm{~Hz}, 3 \mathrm{H}, \mathrm{CH}_{3}\right)$, $4.36\left(\mathrm{q}, J=7.3 \mathrm{~Hz}, 2 \mathrm{H}, \mathrm{COOCH}_{2}\right), 7.03(\mathrm{dd}, J=10.3,5.9 \mathrm{~Hz}$, $\left.1 \mathrm{H}, E-\mathrm{C}_{1}^{\prime}-\mathrm{H}\right), 7.25\left(\mathrm{dd}, J=10.7,6.4 \mathrm{~Hz}, 1 \mathrm{H}, \mathrm{C}_{8}-\mathrm{H}\right), 7.47(\mathrm{dd}$, $\left.J=74.5,10.3 \mathrm{~Hz}, 1 \mathrm{H}, E-\mathrm{C}_{2}{ }^{\prime}-\mathrm{H}\right), 8.16(\mathrm{dd}, J=10.3,8.3 \mathrm{~Hz}$, $\left.1 \mathrm{H}, \mathrm{C}_{5}-\mathrm{H}\right), 8.37\left(\mathrm{~s}, 1 \mathrm{H}, \mathrm{C}_{2}-\mathrm{H}\right)$. MS (EI) $\mathrm{m} / z: 297\left(\mathrm{M}^{+}\right)$. HRMS (EI) for $\mathrm{C}_{14} \mathrm{H}_{10} \mathrm{~F}_{3} \mathrm{NO}_{3}\left(\mathrm{M}^{+}\right)$: calcd, 297.0613; found, 297.0638 . Anal. $\left(\mathrm{C}_{14} \mathrm{H}_{10} \mathrm{~F}_{3} \mathrm{NO}_{3}\right) \mathrm{C}, \mathrm{H}, \mathrm{N}$.

Ethyl 6,7,8-Trifluoro-1-(2-fluorovinyl)-1,4-dihydro-4oxo-3-quinolinecarboxylate (13b). The compound 13b $(780$ $\mathrm{mg}, 93 \%)$ was prepared from $12 \mathrm{~b}(1.25 \mathrm{~g}, 2.65 \mathrm{mmol})$ by the same method as that used for 13a. Mp: $141-143{ }^{\circ} \mathrm{C} .{ }^{1} \mathrm{H}$ NMR $\left(\mathrm{CDCl}_{3}\right) \delta:$ 1.39-1.42 $\left(\mathrm{m}, 3 \mathrm{H}, \mathrm{CH}_{3}\right), 4.36-4.42(\mathrm{~m}, 2 \mathrm{H}$, $\mathrm{COOCH}_{2}$ ), 6.67 (ddd, $J=25.9,9.3,3.4 \mathrm{~Hz}, 0.5 \mathrm{H}, Z-\mathrm{C}_{1}{ }^{\prime}-\mathrm{H}$ ), 6.91 (ddd, $J=75.2,3.4,2.0 \mathrm{~Hz}, 0.5 \mathrm{H}, Z-\mathrm{C}_{2}{ }^{\prime}-\mathrm{H}$ ), 7.39 (ddd, $J$ $\left.=10.3,10.0,4.4 \mathrm{~Hz}, 0.5 \mathrm{H}, E-\mathrm{C}_{1}{ }^{\prime}-\mathrm{H}\right), 7.43(\mathrm{dd}, J=74.5,10.3$ $\left.\mathrm{Hz}, 0.5 \mathrm{H}, E-\mathrm{C}_{2}{ }^{\prime}-\mathrm{H}\right), 8.05-8.13\left(\mathrm{~m}, 1 \mathrm{H}, \mathrm{C}_{5}-\mathrm{H}\right), 8.05(\mathrm{~s}, 1 \mathrm{H}$, $\left.E-\mathrm{C}_{2}-\mathrm{H}\right), 8.36\left(\mathrm{~d}, J=1.5 \mathrm{~Hz}, 0.5 \mathrm{H}, \mathrm{C}_{2}-\mathrm{H}\right)$. IR $(\mathrm{KBr}) \mathrm{cm}^{-1}$ : 1730, 1691, 1628. MS m/z: $315\left(\mathrm{M}^{+}\right)$. Anal. $\left(\mathrm{C}_{14} \mathrm{H}_{9} \mathrm{~F}_{4} \mathrm{NO}_{3}\right) \mathrm{C}$, $\mathrm{H}, \mathrm{N}$.

Ethyl 6,7-Difluoro-1-(2-fluorovinyl)-1,4-dihydro-8-methoxy-4-oxo-3-quinolinecarboxylate (13c). The compound 13c $(1.09 \mathrm{~g}, 81 \%)$ was prepared from $12 \mathrm{c}(2.00 \mathrm{~g}, 4.14 \mathrm{mmol})$ by the same method as that used for 13a. Mp: $177-178^{\circ} \mathrm{C}$. ${ }^{1} \mathrm{H} \mathrm{NMR}\left(\mathrm{CDCl}_{3}\right) \delta: 1.47\left(\mathrm{t}, J=7.3 \mathrm{~Hz}, 3 \mathrm{H}, \mathrm{CH}_{3}\right), 3.95(\mathrm{~d}, J$ $\left.=1.0 \mathrm{~Hz}, 1 \mathrm{H}, \mathrm{OCH}_{3}\right), 3.98\left(\mathrm{~d}, J=1.5 \mathrm{~Hz}, 2 \mathrm{H}, \mathrm{OCH}_{3}\right), 4.36-$ $4.42\left(\mathrm{~m}, 2 \mathrm{H}, \mathrm{CH}_{2}\right), 6.78\left(\mathrm{~s}, 0.3 \mathrm{H}, Z-\mathrm{C}_{1}{ }^{\prime}-\mathrm{H}\right), 6.91(\mathrm{dd}, J=51.3$, $\left.3.9 \mathrm{~Hz}, 0.3 \mathrm{H}, Z-\mathrm{C}_{2}{ }^{\prime}-\mathrm{H}\right), 7.26(\mathrm{dd}, J=75.6,10.3 \mathrm{~Hz}, 0.7 \mathrm{H}$, $Z-\mathrm{C}_{2}{ }^{\prime}-\mathrm{H}$ ), 7.55 (dd, $\left.J=10.3,6.8 \mathrm{~Hz}, 0.7 \mathrm{H}, E-\mathrm{C}_{1}{ }^{\prime}-\mathrm{H}\right), 8.00-$ $8.09\left(\mathrm{~m}, 1 \mathrm{H}, \mathrm{C}_{5}-\mathrm{H}\right), 8.29\left(\mathrm{~s}, 0.7 \mathrm{H}, E-\mathrm{C}_{2}-\mathrm{H}\right), 8.35(\mathrm{~d}, J=2.0$ $\left.\mathrm{Hz}, 0.3 \mathrm{H}, \mathrm{C}_{2}-\mathrm{H}\right)$. IR $(\mathrm{KBr}) \mathrm{cm}^{-1}: 1730,1617$. MS $\mathrm{m} / z: 327$ $\left(\mathrm{M}^{+}\right)$. Anal. $\left(\mathrm{C}_{15} \mathrm{H}_{12} \mathrm{~F}_{3} \mathrm{NO}_{4}\right) \mathrm{C}, \mathrm{H}, \mathrm{N}$.

6,7-Difluoro-1-[(Z)-2-fluorovinyl]-1,4-dihydro-4-oxo-3quinolinecarboxylic Acid ( $\boldsymbol{Z}$-14a). A mixture of $\boldsymbol{Z}$-13a $(273$ $\mathrm{mg}, 1.01 \mathrm{mmol})$, concentrated $\mathrm{H}_{2} \mathrm{SO}_{4}(0.7 \mathrm{~mL}), \mathrm{AcOH}(3.5 \mathrm{~mL})$, and water $(3.5 \mathrm{~mL})$ was stirred at $100{ }^{\circ} \mathrm{C}$ for $1 \mathrm{~h}$ and then poured into ice/water. The resulting precipitates were collected by filtration, washed with water, and then dried in vacuo to give $Z \mathbf{- 1 4 a}(228 \mathrm{mg}, 92 \%)$ as a white solid. $\mathrm{Mp}: 201-204{ }^{\circ} \mathrm{C}$. ${ }^{1} \mathrm{H} \mathrm{NMR}\left(\mathrm{CDCl}_{3}\right) \delta: 6.46\left(\mathrm{dd}, J=25.2,3.4 \mathrm{~Hz}, 1 \mathrm{H}, \mathrm{C}_{1}{ }^{\prime}-\mathrm{H}\right)$, 7.12 (dd, $J=73.8,3.4 \mathrm{~Hz}, 1 \mathrm{H}, \mathrm{C}_{2}{ }^{\prime}-\mathrm{H}$ ), 7.41 (dd, $J=9.5,6.4$ $\left.\mathrm{Hz}, 1 \mathrm{H}, \mathrm{C}_{8}-\mathrm{H}\right), 8.32\left(\mathrm{dd}, J=9.8,8.3 \mathrm{~Hz}, 1 \mathrm{H}, \mathrm{C}_{5}-\mathrm{H}\right), 8.75(\mathrm{~d}$, $\left.J=1.0 \mathrm{~Hz}, 1 \mathrm{H}, \mathrm{C}_{2}-\mathrm{H}\right)$. IR $(\mathrm{KBr}) \mathrm{cm}^{-1}: 1720,1618 . \mathrm{MS} \mathrm{m} / z$ : $269\left(\mathrm{M}^{+}\right)$. HRMS for $\mathrm{C}_{12} \mathrm{H}_{6} \mathrm{~F}_{3} \mathrm{NO}_{3}\left(\mathrm{M}^{+}\right)$: calcd, 269.0300; found, 269.0302. Anal. $\left(\mathrm{C}_{12} \mathrm{H}_{6} \mathrm{~F}_{3} \mathrm{NO}_{3}\right) \mathrm{C}, \mathrm{H}, \mathrm{N}$.

6,7-Difluoro-1-[(E)-2-fluorovinyl]-1,4-dihydro-4-oxo-3quinolinecarboxylic Acid $(E-14 a)$. The compound $E$-14a (413 mg, 93\%) was prepared from $E$-13a (489 mg, $1.82 \mathrm{mmol})$ by the same method as that used for Z-14a. Mp: 267-269 ${ }^{\circ} \mathrm{C} .{ }^{1} \mathrm{H} \mathrm{NMR}\left(\mathrm{CDCl}_{3}\right) \delta: 7.12\left(\mathrm{dd}, J=10.5,5.9 \mathrm{~Hz}, 1 \mathrm{H}, \mathrm{C}_{1}{ }^{\prime}-\right.$ $\mathrm{H}), 7.41\left(\mathrm{dd}, J=73.6,10.3 \mathrm{~Hz}, 1 \mathrm{H}, \mathrm{C}_{2}{ }^{\prime}-\mathrm{H}\right), 7.43(\mathrm{dd}, J=10.3$, $\left.6.4 \mathrm{~Hz}, 1 \mathrm{H}, \mathrm{C}_{8}-\mathrm{H}\right), 8.32\left(\mathrm{dd}, J=9.5,8.3 \mathrm{~Hz}, 1 \mathrm{H}, \mathrm{C}_{5}-\mathrm{H}\right), 8.73$ $\left(\mathrm{s}, 1 \mathrm{H}, \mathrm{C}_{2}-\mathrm{H}\right)$. IR $(\mathrm{KBr}) \mathrm{cm}^{-1}: 1732,1618$. MS m/z: $269\left(\mathrm{M}^{+}\right)$. HRMS for $\mathrm{C}_{12} \mathrm{H}_{6} \mathrm{~F}_{3} \mathrm{NO}_{3}\left(\mathrm{M}^{+}\right)$: calcd, 269.0300; found, 269.0328. Anal. $\left(\mathrm{C}_{12} \mathrm{H}_{6} \mathrm{~F}_{3} \mathrm{NO}_{3}\right) \mathrm{C}, \mathrm{H}, \mathrm{N}$.

6,7,8-Trifluoro-1-(2-fluorovinyl)-1,4-dihydro-4-oxo-3quinolinecarboxylic Acid (14b). The compound 14b (123 $\mathrm{mg}, 93 \%)$ was prepared from $13 \mathbf{b}(145 \mathrm{mg}, 0.460 \mathrm{mmol})$ by the same method as that used for $Z$-14a. Mp: $268-271^{\circ} \mathrm{C}$. ${ }^{1} \mathrm{H} \mathrm{NMR}\left(\mathrm{CDCl}_{3}\right) \delta: 6.67$ (ddd, $J=24.7,9.8,3.5 \mathrm{~Hz}, 0.5 \mathrm{H}$, $Z-\mathrm{C}_{1}{ }^{\prime}-\mathrm{H}$ ), 7.00 (ddd, $J=74.6,3.5,2.0 \mathrm{~Hz}, 0.5 \mathrm{H}, Z-\mathrm{C}_{2}{ }^{\prime}-\mathrm{H}$ ), 7.35 (dd, $J=71.6,9.8 \mathrm{~Hz}, 0.5 \mathrm{H}, E-\mathrm{C}_{2}{ }^{\prime}-\mathrm{H}$ ), 7.46 (ddd, $J=10.1$, $\left.9.8,6.8 \mathrm{~Hz}, 0.5 \mathrm{H}, E-\mathrm{C}_{1}{ }^{\prime}-\mathrm{H}\right), 8.14-8.20\left(\mathrm{~m}, 1 \mathrm{H}, \mathrm{C}_{5}-\mathrm{H}\right), 8.62$ $\left(\mathrm{s}, 1 \mathrm{H}, E-\mathrm{C}_{2}-\mathrm{H}\right), 8.65\left(\mathrm{~d}, J=1.5 \mathrm{~Hz}, 0.5 \mathrm{H}, Z-\mathrm{C}_{2}-\mathrm{H}\right) . \mathrm{IR}(\mathrm{KBr})$ $\mathrm{cm}^{-1}$ : 1728, 1618. MS m/z: $287\left(\mathrm{M}^{+}\right)$. Anal. $\left(\mathrm{C}_{12} \mathrm{H}_{5} \mathrm{~F}_{4} \mathrm{NO}_{3}\right.$. $\left.0.25 \mathrm{H}_{2} \mathrm{O}\right) \mathrm{C}, \mathrm{H}, \mathrm{N}$.

6,7-Difluoro-1-(2-fluorovinyl)-1,4-dihydro-8-methoxy4-oxo-3-quinolinecarboxylic Acid (14c). The compound 14c (913 mg, 96\%) was prepared from 13c $(1.04 \mathrm{~g}, 3.18 \mathrm{mmol})$ by the same method as that used for $Z$-14a. Mp: $230-232^{\circ} \mathrm{C}$. ${ }^{1} \mathrm{H}$ NMR (DMSO- $\left.d_{6}\right) \delta: 3.93\left(\mathrm{~d}, J=1.0 \mathrm{~Hz}, 2.1 \mathrm{H}, E-\mathrm{OCH}_{3}\right.$ ), $3.95\left(\mathrm{~d}, J=1.5 \mathrm{~Hz}, 0.9 \mathrm{H}, Z-\mathrm{OCH}_{3}\right), 7.13$ (ddd, $J=28.9,3.4$ $\left.\mathrm{Hz}, 0.3 \mathrm{H}, Z-\mathrm{C}_{1}{ }^{\prime}-\mathrm{H}\right), 7.40$ (ddd, $J=76.8,3.4 \mathrm{~Hz}, 0.3 \mathrm{H}, Z-\mathrm{C}_{2}{ }^{\prime}-$ $\mathrm{H}), 7.70\left(\mathrm{dd}, J=16.1,10.3 \mathrm{~Hz}, 0.7 \mathrm{H}, E-\mathrm{C}_{1}{ }^{\prime}-\mathrm{H}\right), 7.81(\mathrm{dd}, J=$ 81.7, $10.3 \mathrm{~Hz}, 0.7 \mathrm{H}, E-\mathrm{C}_{2}{ }^{\prime}-\mathrm{H}$ ), 8.07 (dd, $J=10.3,8.3 \mathrm{~Hz}, 0.3 \mathrm{H}$, $\left.Z-\mathrm{C}_{5}-\mathrm{H}\right), 8.09\left(\mathrm{dd}, J=10.3,8.3 \mathrm{~Hz}, 0.7 \mathrm{H}, E-\mathrm{C}_{5}-\mathrm{H}\right), 8.59(\mathrm{~d}$, $\left.J=1.5 \mathrm{~Hz}, 0.3 \mathrm{H}, Z-\mathrm{C}_{2}-\mathrm{H}\right), 8.63\left(\mathrm{~s}, 0.7 \mathrm{H}, E-\mathrm{C}_{2}-\mathrm{H}\right), 14.3(\mathrm{br}$, $0.3 \mathrm{H}, \mathrm{COOH}), 14.4(\mathrm{~s}, 0.7 \mathrm{H}, \mathrm{COOH}) . \mathrm{IR}(\mathrm{KBr}) \mathrm{cm}^{-1}: 1736$, 1617. MS m/z: $299\left(\mathrm{M}^{+}\right)$. Anal. $\left(\mathrm{C}_{13} \mathrm{H}_{8} \mathrm{~F}_{3} \mathrm{NO}_{4}\right) \mathrm{C}, \mathrm{H}, \mathrm{N}$.

6-Fluoro-1-[(Z)-2-fluorovinyl]-1,4-dihydro-7-(4-methyl1-piperazinyl)-4-oxo-3-quinolinecarboxylic Acid ( $Z$-15a). A mixture of $Z$-14a (60 mg, $0.223 \mathrm{mmol}), N$-methylpiperazine $(54.0 \mu \mathrm{L}, 0.487 \mathrm{mmol})$, and DMSO $(1 \mathrm{~mL})$ was stirred at $60^{\circ} \mathrm{C}$ for $1 \mathrm{~h}$ and then concentrated in vacuo. Flash chromatography $\left(\mathrm{CH}_{2} \mathrm{Cl}_{2} / \mathrm{MeOH} / 25 \% \quad \mathrm{NH}_{4} \mathrm{OH}=20: 5: 1\right)$ of the residue gave Z-15a (21 mg, 27\%) as a white powder. Mp: $196-199{ }^{\circ} \mathrm{C} .{ }^{1} \mathrm{H}$ $\operatorname{NMR}\left(\mathrm{CDCl}_{3}\right) \delta: 2.38\left(\mathrm{~s}, 3 \mathrm{H}, \mathrm{CH}_{3}\right), 2.62-2.65\left(\mathrm{~m}, 4 \mathrm{H}, \mathrm{CH}_{2} \times\right.$ 2), 3.33-3.38 (m, $\left.4 \mathrm{H}, \mathrm{CH}_{2} \times 2\right), 6.42(\mathrm{dd}, J=25.9,3.4 \mathrm{~Hz}$, $\left.1 \mathrm{H}, \mathrm{C}_{1}{ }^{\prime}-\mathrm{H}\right), 6.77\left(\mathrm{~d}, J=6.4 \mathrm{~Hz}, 1 \mathrm{H}, \mathrm{C}_{8}-\mathrm{H}\right), 7.06(\mathrm{dd}, J=74.3$, $\left.3.4 \mathrm{~Hz}, 1 \mathrm{H}, \mathrm{C}_{2}{ }^{\prime}-\mathrm{H}\right), 8.05\left(\mathrm{~d}, J=12.7 \mathrm{~Hz}, 1 \mathrm{H}, \mathrm{C}_{5}-\mathrm{H}\right), 8.65(\mathrm{~d}$, $\left.J=1.0 \mathrm{~Hz}, 1 \mathrm{H}, \mathrm{C}_{2}-\mathrm{H}\right), 14.5-15.0$ (br, $\left.1 \mathrm{H}, \mathrm{COOH}\right) . \mathrm{IR}(\mathrm{KBr})$ $\mathrm{cm}^{-1}:$ 1728, 1628. MS m/z: $349\left(\mathrm{M}^{+}\right)$. HRMS for $\mathrm{C}_{17} \mathrm{H}_{17} \mathrm{~F}_{2} \mathrm{~N}_{3} \mathrm{O}_{3}$ $\left(\mathrm{M}^{+}\right)$: calcd, 349.1238; found, 349.1203. Anal. $\left(\mathrm{C}_{17} \mathrm{H}_{17} \mathrm{~F}_{2} \mathrm{~N}_{3} \mathrm{O}_{3}\right)$ $\mathrm{C}, \mathrm{H}, \mathrm{N}$.

6-Fluoro-1-[(E)-2-fluorovinyl]-1,4-dihydro-7-(4-methyl1-piperazinyl)-4-oxo-3-quinolinecarboxylic Acid $(E-15 a)$. The compound $E$-15a (96 mg, $74 \%$ ) was prepared from $E$-14a $(100 \mathrm{mg}, 0.371 \mathrm{mmol})$ by the same method as that used for $Z$-15a. Mp: $249-251^{\circ} \mathrm{C} .{ }^{1} \mathrm{H}$ NMR $\left(\mathrm{CDCl}_{3}\right) \delta: 2.39\left(\mathrm{~s}, 3 \mathrm{H}, \mathrm{CH}_{3}\right)$, $2.62-2.65\left(\mathrm{~m}, 4 \mathrm{H}, \mathrm{CH}_{2} \times 2\right), 3.35-3.38\left(\mathrm{~m}, 4 \mathrm{H}, \mathrm{CH}_{2} \times 2\right), 6.77$ (d, $\left.1 \mathrm{H}, J=6.8 \mathrm{~Hz}, \mathrm{C}_{8}-\mathrm{H}\right), 7.12(\mathrm{dd}, J=10.3,6.4 \mathrm{~Hz}, 1 \mathrm{H}$, $\left.\mathrm{C}_{1}{ }^{\prime}-\mathrm{H}\right), 7.13\left(\mathrm{dd}, J=74.6,10.3 \mathrm{~Hz}, 1 \mathrm{H}, \mathrm{C}_{2}{ }^{\prime}-\mathrm{H}\right), 8.04(\mathrm{~d}, J=$ $\left.13.2 \mathrm{~Hz}, 1 \mathrm{H}, \mathrm{C}_{5}-\mathrm{H}\right), 8.61\left(\mathrm{~s}, 1 \mathrm{H}, \mathrm{C}_{2}-\mathrm{H}\right)$. IR $(\mathrm{KBr}) \mathrm{cm}^{-1}: 1721$, 1630. MS m/z: $349\left(\mathrm{M}^{+}\right)$. HRMS for $\mathrm{C}_{17} \mathrm{H}_{17} \mathrm{~F}_{2} \mathrm{~N}_{3} \mathrm{O}_{3}\left(\mathrm{M}^{+}\right)$: calcd, 349.1238; found, 349.1278. Anal. $\left(\mathrm{C}_{17} \mathrm{H}_{17} \mathrm{~F}_{2} \mathrm{~N}_{3} \mathrm{O}_{3}\right) \mathrm{C}, \mathrm{H}, \mathrm{N}$.

6,8-Difluoro-1-[(Z)-2-fluorovinyl]-1,4-dihydro-7-(4-methyl-1-piperazinyl)-4-oxo-3-quinolinecarboxylic Acid ( $Z$ 15b) and 6,8-Difluoro-1-[(E)-2-fluorovinyl]-1,4-dihydro7-(4-methyl-1-piperazinyl)-4-oxo-3-quinolinecarboxylic Acid (E-15b). A mixture of $14 b(50 \mathrm{mg}, 0.174 \mathrm{mmol}), N$ methylpiperazine $(43.0 \mu \mathrm{L}, 0.387 \mathrm{mmol})$, and DMSO $(1 \mathrm{~mL})$ 
was stirred at $60{ }^{\circ} \mathrm{C}$ for $1 \mathrm{~h}$ and then concentrated in vacuo. Preparative TLC $\left(\mathrm{CH}_{2} \mathrm{Cl}_{2} / \mathrm{MeOH}=10: 1\right)$ of the residue gave $E$-15b $\left(R_{f}=0.40,34 \mathrm{mg}, 53 \%\right)$ as a white solid and $Z$-15b $\left(R_{f}\right.$ $=0.36,18 \mathrm{mg}, 26 \%)$ as a pale-brown solid.

Z-15b. Mp: $203-205{ }^{\circ} \mathrm{C} .{ }^{1} \mathrm{H}$ NMR $\left(\mathrm{CDCl}_{3}\right) \delta: 2.37$ (s, 3H, $\mathrm{CH}_{3}$ ), 2.57 (br, $4 \mathrm{H}, \mathrm{CH}_{2} \times 2$ ), $3.43\left(\mathrm{br}, 4 \mathrm{H}, \mathrm{CH}_{2} \times 2\right), 6.72$ (ddd, $\left.J=25.9,10.8,3.4 \mathrm{~Hz}, 1 \mathrm{H}, \mathrm{C}_{1}^{\prime}-\mathrm{H}\right), 6.91(\mathrm{dd}, J=74.3,3.4,2.0$ $\left.\mathrm{Hz}, 1 \mathrm{H}, \mathrm{C}_{2}^{\prime}-\mathrm{H}\right), 7.29\left(\mathrm{dd}, J=12.7,2.0 \mathrm{~Hz}, 1 \mathrm{H}, \mathrm{C}_{5}-\mathrm{H}\right), 8.56$ (d, $\left.J=1.5 \mathrm{~Hz}, 1 \mathrm{H}, \mathrm{C}_{2}-\mathrm{H}\right), 14.5-14.7$ (br, $\left.1 \mathrm{H}, \mathrm{COOH}\right) . \mathrm{IR}(\mathrm{KBr})$ $\mathrm{cm}^{-1}$ : 1657. $\mathrm{MS} \mathrm{m} / z: 367\left(\mathrm{M}^{+}\right)$. Anal. $\left(\mathrm{C}_{17} \mathrm{H}_{16} \mathrm{~F}_{3} \mathrm{~N}_{3} \mathrm{O}_{3} \cdot 0.75 \mathrm{H}_{2} \mathrm{O}\right)$ C, H, N.

$\boldsymbol{E}$-15b. Mp: $248-251{ }^{\circ} \mathrm{C} .{ }^{1} \mathrm{H}$ NMR $\left(\mathrm{CDCl}_{3}\right) \delta: 2.37(\mathrm{~s}, 3 \mathrm{H}$, $\mathrm{CH}_{3}$ ), 2.57 (br, $4 \mathrm{H}, \mathrm{CH}_{2} \times 2$ ), $3.44\left(\mathrm{br}, 4 \mathrm{H}, \mathrm{CH}_{2} \times 2\right), 7.26$ (ddd, $J=73.6,10.3,3.4 \mathrm{~Hz}, 1 \mathrm{H}, \mathrm{C}_{2}{ }^{\prime}-\mathrm{H}$ ), 7.44 (ddd, $J=11.9,10.3$, $\left.6.4 \mathrm{~Hz}, 1 \mathrm{H}, \mathrm{C}_{1}^{\prime}-\mathrm{H}\right), 7.92\left(\mathrm{dd}, J=13.2,2.0 \mathrm{~Hz}, 1 \mathrm{H}, \mathrm{C}_{5}-\mathrm{H}\right)$, $8.56\left(\mathrm{~s}, 1 \mathrm{H}, \mathrm{C}_{2}-\mathrm{H}\right)$. IR $(\mathrm{KBr}) \mathrm{cm}^{-1}: 1725,1620 . \mathrm{MS} \mathrm{m} / z: 367$ $\left(\mathrm{M}^{+}\right)$. Anal. $\left(\mathrm{C}_{17} \mathrm{H}_{16} \mathrm{~F}_{3} \mathrm{~N}_{3} \mathrm{O}_{3} \cdot 0.25 \mathrm{H}_{2} \mathrm{O}\right) \mathrm{C}, \mathrm{H}, \mathrm{N}$.

6-Difluoro-1-[(Z)-2-fluorovinyl]-1,4-dihydro-8-methoxy7-(4-methyl-1-piperazinyl)-4-oxo-3-quinolinecarboxylic Acid $(Z-15 c)$ and 6-Difluoro-1-[(E)-2-fluorovinyl]-1,4dihydro-8-methoxy-7-(4-methyl-1-piperazinyl)-4-oxo-3quinolinecarboxylic Acid $(\boldsymbol{E}$-15c). The compounds $Z$-15c $(15.0 \mathrm{mg}, 12 \%)$ and $E$-15c $(30.4 \mathrm{mg}, 24 \%)$ were prepared from 14c (100 $\mathrm{mg}, 0.334 \mathrm{mmol})$ by the same method as that used for $Z$-15c and $E$-15c.

Z-15c. Mp: $172-175{ }^{\circ} \mathrm{C} .{ }^{1} \mathrm{H} \mathrm{NMR}\left(\mathrm{CDCl}_{3}\right) \delta: 2.39(\mathrm{~s}, 3 \mathrm{H}$, $\mathrm{CH}_{3}$ ), 2.52-2.63 (br, $\left.4 \mathrm{H}, \mathrm{CH}_{2} \times 2\right), 3.43-3.49$ (br, $4 \mathrm{H}, \mathrm{CH}_{2} \times$ 2), $3.71\left(\mathrm{~s}, 3 \mathrm{H}, \mathrm{CH}_{3}\right), 6.78\left(\mathrm{dd}, J=17.6,3.4 \mathrm{~Hz}, 1 \mathrm{H}, \mathrm{C}_{1}^{\prime}-\mathrm{H}\right)$, $6.91\left(\mathrm{dd}, J=66.5,3.4 \mathrm{~Hz}, 1 \mathrm{H}, \mathrm{C}_{2}{ }^{\prime}-\mathrm{H}\right), 7.92(\mathrm{~d}, J=12.2 \mathrm{~Hz}$, $\left.1 \mathrm{H}, \mathrm{C}_{5}-\mathrm{H}\right), 8.58\left(\mathrm{~d}, J=2.0 \mathrm{~Hz}, 1 \mathrm{H}, \mathrm{C}_{2}-\mathrm{H}\right), 14.4-14.8$ (br, $1 \mathrm{H}, \mathrm{COOH})$. IR (KBr) $\mathrm{cm}^{-1}: 1733,1619$. MS (EI) $\mathrm{m} / \mathrm{z}: 379$ $\left(\mathrm{M}^{+}\right)$. HRMS (EI) for $\mathrm{C}_{18} \mathrm{H}_{19} \mathrm{~F}_{2} \mathrm{~N}_{3} \mathrm{O}_{4}\left(\mathrm{M}^{+}\right)$: calcd, 379.1344; found, 379.1340. Anal. $\left(\mathrm{C}_{18} \mathrm{H}_{19} \mathrm{~F}_{2} \mathrm{~N}_{3} \mathrm{O}_{4} \cdot 0.25 \mathrm{H}_{2} \mathrm{O}\right) \mathrm{C}, \mathrm{H}, \mathrm{N}$.

E-15c. Mp: $229-232{ }^{\circ} \mathrm{C} .{ }^{1} \mathrm{H}$ NMR $\left(\mathrm{CDCl}_{3}\right) \delta: 2.39(\mathrm{~s}, 3 \mathrm{H}$, $\mathrm{CH}_{3}$ ), 2.57-2.59 (br, $4 \mathrm{H}, \mathrm{CH}_{2} \times 2$ ), 3.43-3.45 (br, $4 \mathrm{H}, \mathrm{CH}_{2} \times$ $2), 3.73\left(\mathrm{~s}, 3 \mathrm{H}, \mathrm{CH}_{3}\right), 7.27\left(\mathrm{dd}, J=74.8,10.3 \mathrm{~Hz}, 1 \mathrm{H}, \mathrm{C}_{2}^{\prime}-\mathrm{H}\right)$, $7.60\left(\mathrm{dd}, J=10.3,6.8 \mathrm{~Hz}, 1 \mathrm{H}, \mathrm{C}_{1}{ }^{\prime}-\mathrm{H}\right), 7.90(\mathrm{~d}, J=11.7 \mathrm{~Hz}$, $\left.1 \mathrm{H}, \mathrm{C}_{5}-\mathrm{H}\right), 8.52\left(\mathrm{~s}, 1 \mathrm{H}, \mathrm{C}_{2}-\mathrm{H}\right), 14.4-14.7$ (br, $\left.1 \mathrm{H}, \mathrm{COOH}\right)$. IR $(\mathrm{KBr}) \mathrm{cm}^{-1}$ : 1624. MS (EI) $\mathrm{m} / z: 379\left(\mathrm{M}^{+}\right)$. HRMS (EI) for $\mathrm{C}_{18} \mathrm{H}_{19} \mathrm{~F}_{2} \mathrm{~N}_{3} \mathrm{O}_{4}\left(\mathrm{M}^{+}\right)$: calcd, 379.1344; found, 379.1327. Anal. $\left(\mathrm{C}_{18} \mathrm{H}_{19} \mathrm{~F}_{2} \mathrm{~N}_{3} \mathrm{O}_{4} \cdot 0.25 \mathrm{H}_{2} \mathrm{O}\right) \mathrm{C}, \mathrm{H}, \mathrm{N}$.

7-(3-Amino-1-pyrrolidinyl)-6-fluoro-1-[(Z)-2-fluorovinyl]1,4-dihydro-4-oxo-3-quinolinecarboxylic Acid Hydrochloride (Z-16a). A mixture of $Z$-14a $(60 \mathrm{mg}, 0.223 \mathrm{mmol})$, 3-Boc-aminopyrrolidine (50 mg, $0.268 \mathrm{mmol}), 1,8$-diazabicyclo[5.4.0] undec-7-ene ( $34 \mu \mathrm{L}, 0.227 \mathrm{mmol})$, and $\mathrm{MeCN}(2 \mathrm{~mL})$ was heated under reflux for $1 \mathrm{~h}$ and concentrated in vacuo. After dilution of the residue with $\mathrm{CH}_{2} \mathrm{Cl}_{2}(20 \mathrm{~mL})$, the mixture was successively washed with water $(5 \mathrm{~mL})$, aqueous $10 \%$ citric acid solution $(2 \times 5 \mathrm{~mL})$, and water $(5 \mathrm{~mL})$. The mixture was then dried over anhydrous $\mathrm{Na}_{2} \mathrm{SO}_{4}$ and concentrated in vacuo. The residue was suspended in saturated $\mathrm{HCl}$ in AcOEt solution $(2 \mathrm{~mL})$, and the mixture was allowed to stand at room temperature for $30 \mathrm{~min}$. The resulting precipitates were collected by filtration, washed with AcOEt, and then dried in vacuo to give $Z \mathbf{- 1 6 a}$ (76 mg, 92\%) as yellow crystals. Mp: $263-$ $270{ }^{\circ} \mathrm{C} .{ }^{1} \mathrm{H}$ NMR (DMSO- $\left.d_{6}+\mathrm{CF}_{3} \mathrm{COOD}\right) \delta: 2.09-2.16(\mathrm{~m}$, $\left.1 \mathrm{H}, \mathrm{CH}_{2}\right), 2.27-2.36\left(\mathrm{~m}, 1 \mathrm{H}, \mathrm{CH}_{2}\right), 3.57-3.97\left(\mathrm{~m}, 5 \mathrm{H}, \mathrm{CH}, \mathrm{CH}_{2}\right.$ $\times 2), 6.61\left(\mathrm{~d}, J=7.3 \mathrm{~Hz}, 1 \mathrm{H}, \mathrm{C}_{8}-\mathrm{H}\right), 7.07(\mathrm{dd}, J=9.3,3.4 \mathrm{~Hz}$, $\left.1 \mathrm{H}, \mathrm{C}_{1}{ }^{\prime}-\mathrm{H}\right), 7.49\left(\mathrm{dd}, J=76.2,3.4 \mathrm{~Hz}, 1 \mathrm{H}, \mathrm{C}_{2}{ }^{\prime}-\mathrm{H}\right), 7.87(\mathrm{~d}, J$ $\left.=14.2 \mathrm{~Hz}, 1 \mathrm{H}, \mathrm{C}_{5}-\mathrm{H}\right), 8.59\left(\mathrm{~d}, J=1.0 \mathrm{~Hz}, 1 \mathrm{H}, \mathrm{C}_{2}-\mathrm{H}\right)$. IR $(\mathrm{KBr}) \mathrm{cm}^{-1}: 1688,1634$. MS (EI) $\mathrm{m} / z: 335\left(\mathrm{M}^{+}\right)$. HRMS for $\mathrm{C}_{16} \mathrm{H}_{15} \mathrm{~F}_{2} \mathrm{~N}_{3} \mathrm{O}_{3}\left(\mathrm{M}^{+}\right)$: calcd, 335.1081; found: 335.1040. Anal. $\left(\mathrm{C}_{16} \mathrm{H}_{15} \mathrm{~F}_{2} \mathrm{~N}_{3} \mathrm{O}_{3} \cdot \mathrm{HCl} \cdot 2.75 \mathrm{H}_{2} \mathrm{O}\right) \mathrm{C}, \mathrm{H}, \mathrm{N}$.

7-(3-Amino-1-pyrrolidinyl)-6-fluoro-1-[(E)-2-fluorovinyl]1,4-dihydro-4-oxo-3-quinolinecarboxylic Acid Hydrochloride ( $\boldsymbol{E}$-16a). The compound $\boldsymbol{E}$-16a $(66 \mathrm{mg}, 48 \%)$ was prepared from $\boldsymbol{E} \mathbf{- 1 4 a}(100 \mathrm{mg}, 0.371 \mathrm{mmol})$ by the same method as that used for Z-16a. Mp: $276-285{ }^{\circ} \mathrm{C}$. ${ }^{1} \mathrm{H}$ NMR (DMSO- $\left.d_{6}+\mathrm{CF}_{3} \mathrm{COOD}\right) \delta: 2.10-2.18\left(\mathrm{~m}, 1 \mathrm{H}, \mathrm{CH}_{2}\right), 2.28-2.37$ (m, 1H, $\left.\mathrm{CH}_{2}\right), 3.59-4.02\left(\mathrm{~m}, 5 \mathrm{H}, \mathrm{CH}, \mathrm{CH}_{2} \times 2\right), 6.62(\mathrm{~d}, J=$ $\left.7.3 \mathrm{~Hz}, 1 \mathrm{H}, \mathrm{C}_{8}-\mathrm{H}\right), 7.74\left(\mathrm{dd}, J=10.3,8.3 \mathrm{~Hz}, 1 \mathrm{H}, \mathrm{C}_{1}^{\prime}-\mathrm{H}\right)$, $7.87\left(\mathrm{~d}, J=14.2 \mathrm{~Hz}, 1 \mathrm{H}, \mathrm{C}_{5}-\mathrm{H}\right), 7.92(\mathrm{dd}, J=75.7,10.3 \mathrm{~Hz}$, $\left.1 \mathrm{H}, \mathrm{C}_{2}{ }^{\prime}-\mathrm{H}\right), 8.62\left(\mathrm{~s}, 1 \mathrm{H}, \mathrm{C}_{2}-\mathrm{H}\right)$. IR $(\mathrm{KBr}) \mathrm{cm}^{-1}$ : $1680,1626$.
MS (EI) $m / z$ : $335\left(\mathrm{M}^{+}\right)$. HRMS for $\mathrm{C}_{16} \mathrm{H}_{15} \mathrm{~F}_{2} \mathrm{~N}_{3} \mathrm{O}_{3}\left(\mathrm{M}^{+}\right)$: calcd, 335.1081; Found, 335.1063. Anal. $\left(\mathrm{C}_{16} \mathrm{H}_{15} \mathrm{~F}_{2} \mathrm{~N}_{3} \mathrm{O}_{3} \mathrm{HCl} 0.5 \mathrm{H}_{2} \mathrm{O}\right)$ C, H, N.

7-(3-Amino-1-pyrrolidinyl)-6,8-difluoro-1-[(Z)-2-fluorovinyl]-1,4-dihydro-4-oxo-3-quinolinecarboxylic Acid Hydrochloride (Z-16b) and 7-(3-Amino-1-pyrrolidinyl)6,8-difluoro-1-[(E)-2-fluorovinyl]-1,4-dihydro-4-oxo-3quinolinecarboxylic Acid Hydrochloride $(E-16 b)$. A mixture of $14 \mathbf{b}$ (200 mg, $0.696 \mathrm{mmol}$ ), 3-Boc-aminopyrrolidine (156 $\mathrm{mg}, 0.836 \mathrm{mmol}), 1,8$-diazabicyclo[5.4.0] undec-7-ene $(105 \mu \mathrm{L}$, $0.703 \mathrm{mmol}$ ), and $\mathrm{MeCN}$ ( $5 \mathrm{~mL}$ ) was heated under reflux for 1 $\mathrm{h}$ and then concentrated in vacuo. The residue was dissolved in $\mathrm{CH}_{2} \mathrm{Cl}_{2}(5 \mathrm{~mL})$ and successively washed with water $(2 \mathrm{~mL})$, aqueous $10 \%$ citric acid solution $(2 \times 2 \mathrm{~mL})$, and water $(2 \mathrm{~mL})$. The mixture was then dried over anhydrous $\mathrm{Na}_{2} \mathrm{SO}_{4}$ and concentrated in vacuo. Flash chromatography $\left(\mathrm{CH}_{2} \mathrm{Cl}_{2} / \mathrm{AcOEt}\right.$ $=1: 1$ ) of the residue gave the $Z$-Boc-amino derivative of $Z$-16b (72 $\mathrm{mg}, 23 \%$ ) as a yellow solid and the $E$-Boc-amino derivative of $E-\mathbf{1 6 b}(174 \mathrm{mg}, 55 \%)$ as a yellow solid. A suspension of the $Z$-Boc derivative $(53 \mathrm{mg}, 0.118 \mathrm{mmol})$ in saturated $\mathrm{HCl}$ in AcOEt solution ( $1 \mathrm{~mL}$ ) was stirred at room temperature for 1 $\mathrm{h}$ and then concentrated in vacuo. After $\mathrm{MeOH}(2 \mathrm{~mL})$ was added to the residue, the resulting precipitates were collected by filtration, washed with $\mathrm{MeOH}$, and then dried in vacuo to give $Z$-16b (24 mg, 53\%) as yellow crystals. Following the same procedure, the $E$-Boc-amino derivative $(151 \mathrm{mg}, 0.333 \mathrm{mmol})$ was converted to $E \mathbf{- 1 6 b}$ (89 $\mathrm{mg}, 69 \%$ ), giving a yellow powder.

Z-16b. Mp: $240-244^{\circ} \mathrm{C} .{ }^{1} \mathrm{H}$ NMR (DMSO- $\left.d_{6}\right) \delta: 2.00-2.08$ (m, $\left.1 \mathrm{H}, \mathrm{CH}_{2}\right), 2.19-2.28\left(\mathrm{~m}, 1 \mathrm{H}, \mathrm{CH}_{2}\right), 3.66-3.81\left(\mathrm{~m}, 2 \mathrm{H}, \mathrm{CH}_{2}\right)$, 3.84-4.02 (m, 3H, CH, $\mathrm{CH}_{2}$ ), 7.08 (ddd, $J=28.7,10.5,3.4$ $\left.\mathrm{Hz}, 1 \mathrm{H}, \mathrm{C}_{1}{ }^{\prime}-\mathrm{H}\right), 7.38\left(\mathrm{dt}, J=76.2,2.9 \mathrm{~Hz}, 1 \mathrm{H}, \mathrm{C}_{2}^{\prime}-\mathrm{H}\right), 7.79$ $\left(\mathrm{dd}, J=13.7,1.5 \mathrm{~Hz}, 1 \mathrm{H}, \mathrm{C}_{5}-\mathrm{H}\right), 8.51(\mathrm{~d}, J=1.0 \mathrm{~Hz}, 1 \mathrm{H}$, $\left.\mathrm{C}_{2}-\mathrm{H}\right)$. IR $(\mathrm{KBr}) \mathrm{cm}^{-1}$ : 1723, 1628. MS (EI) $\mathrm{m} / z$ : $353\left(\mathrm{M}^{+}\right)$. Anal. $\left(\mathrm{C}_{16} \mathrm{H}_{14} \mathrm{~F}_{3} \mathrm{~N}_{3} \mathrm{O}_{3} \cdot \mathrm{HCl} \cdot 2 \mathrm{H}_{2} \mathrm{O}\right) \mathrm{C}, \mathrm{H}, \mathrm{N}$.

$\boldsymbol{E}$-16b. Mp: $258-263{ }^{\circ} \mathrm{C} .{ }^{1} \mathrm{H}$ NMR (DMSO- $\left.d_{6}\right) \delta: 2.02-2.10$ $\left(\mathrm{m}, 1 \mathrm{H}, \mathrm{CH}_{2}\right), 2.19-2.28\left(\mathrm{~m}, 1 \mathrm{H}, \mathrm{CH}_{2}\right), 3.69-3.75\left(\mathrm{~m}, 2 \mathrm{H}, \mathrm{CH}_{2}\right)$ 3.75-4.02 (m, 3H, CH, $\mathrm{CH}_{2}$ ), 7.67 (ddd, $J=13.0,10.3,8.3$ $\left.\mathrm{Hz}, 1 \mathrm{H}, \mathrm{C}_{1}{ }^{\prime}-\mathrm{H}\right), 7.80\left(\mathrm{dd}, J=13.7,1.5 \mathrm{~Hz}, 1 \mathrm{H}, \mathrm{C}_{5}-\mathrm{H}\right), 7.86$ (ddd, $\left.J=80.2,10.3,1.5 \mathrm{~Hz}, 1 \mathrm{H}, \mathrm{C}_{2}^{\prime}-\mathrm{H}\right), 8.53\left(\mathrm{~s}, 1 \mathrm{H}, \mathrm{C}_{2}-\mathrm{H}\right)$. IR $(\mathrm{KBr}) \mathrm{cm}^{-1}: 1680,1626$. MS (EI) $\mathrm{m} / z: 353\left(\mathrm{M}^{+}\right)$. Anal. $\left(\mathrm{C}_{16} \mathrm{H}_{14} \mathrm{~F}_{3} \mathrm{~N}_{3} \mathrm{O}_{3} \cdot \mathrm{HCl} \cdot 0.75 \mathrm{H}_{2} \mathrm{O}\right) \mathrm{C}, \mathrm{H}, \mathrm{N}$.

7-(3-Amino-1-pyrrolidinyl)-6-fluoro-1-[(Z)-2-fluorovinyl]1,4-dihydro-8-methoxy-4-oxo-3-quinolinecarboxylic Acid Hydrochloride (Z-16c) and 7-(3-Amino-1-pyrrolidinyl)6-fluoro-1-[(E)-2-fluorovinyl]-1,4-dihydro-8-methoxy-4oxo-3-quinolinecarboxylic Acid Hydrochloride $(E-16 c)$. The compounds $Z$-16c $(14.3 \mathrm{mg}, 6 \%)$ and $E$-16c $(86 \mathrm{mg}, 34 \%)$ were prepared from 14c $(200 \mathrm{mg}, 0.668 \mathrm{mmol})$ by the same method as that used for $Z-16 b$ and $E-\mathbf{1 6 b}$.

Z-16c. Mp: $211-219^{\circ} \mathrm{C} .{ }^{1} \mathrm{H}$ NMR (DMSO- $\left.d_{6}\right) \delta: 1.91-2.08$ $\left(\mathrm{m}, 1 \mathrm{H}, \mathrm{CH}_{2}\right), 2.23-2.39\left(\mathrm{~m}, 1 \mathrm{H}, \mathrm{CH}_{2}\right), 3.51\left(\mathrm{~s}, 3 \mathrm{H}, \mathrm{OCH}_{3}\right)$, 3.56-3.67 (m, $\left.1 \mathrm{H}, \mathrm{CH}_{2}\right), 3.68-3.90\left(\mathrm{~m}, 4 \mathrm{H}, \mathrm{CH}, \mathrm{CH}_{2} \times 2\right), 7.03$ $\left(\mathrm{dd}, J=29.3,3.4 \mathrm{~Hz}, 1 \mathrm{H}, \mathrm{C}_{1}{ }^{\prime}-\mathrm{H}\right), 7.34(\mathrm{dd}, J=76.8,3.4 \mathrm{~Hz}$, $\left.1 \mathrm{H}, \mathrm{C}_{2}{ }^{\prime}-\mathrm{H}\right), 7.76\left(\mathrm{~d}, J=13.7 \mathrm{~Hz}, 1 \mathrm{H}, \mathrm{C}_{5}-\mathrm{H}\right), 8.27(\mathrm{br}, 3 \mathrm{H}$, $\mathrm{NH} \cdot \mathrm{HCl}), 8.49\left(\mathrm{~d}, J=1.0 \mathrm{~Hz}, 1 \mathrm{H}, \mathrm{C}_{2}-\mathrm{H}\right), 14.0-15.5(\mathrm{br}, 1 \mathrm{H}$, $\mathrm{COOH})$. IR (KBr) cm $\mathrm{cm}^{-1}: 1725,1620$. MS (EI) $\mathrm{m} / z: 365\left(\mathrm{M}^{+}\right)$. HRMS (EI) for $\mathrm{C}_{17} \mathrm{H}_{17} \mathrm{~F}_{2} \mathrm{~N}_{3} \mathrm{O}_{4}\left(\mathrm{M}^{+}\right)$: calcd, 365.1187; found, 365.1177. Anal. $\left(\mathrm{C}_{17} \mathrm{H}_{17} \mathrm{~F}_{2} \mathrm{~N}_{3} \mathrm{O}_{4} \cdot \mathrm{HCl} \cdot 0.5 \mathrm{H}_{2} \mathrm{O}\right) \mathrm{C}, \mathrm{H}, \mathrm{N}$.

E-16c. Mp: $180-188^{\circ} \mathrm{C} .{ }^{1} \mathrm{H}$ NMR $\left(\mathrm{DMSO}_{-} d_{6}\right) \delta: 1.91-2.10$ $\left(\mathrm{m}, 1 \mathrm{H}, \mathrm{CH}_{2}\right), 2.22-2.34\left(\mathrm{~m}, 1 \mathrm{H}, \mathrm{CH}_{2}\right), 3.50\left(\mathrm{~s}, 3 \mathrm{H}, \mathrm{OCH}_{3}\right)$, $3.58-3.67\left(\mathrm{~m}, 1 \mathrm{H}, \mathrm{CH}_{2}\right), 3.70-3.96\left(\mathrm{~m}, 4 \mathrm{H}, \mathrm{CH}, \mathrm{CH}_{2} \times 2\right), 7.65$ $\left(\mathrm{dd}, J=10.3,8.3 \mathrm{~Hz}, 1 \mathrm{H}, \mathrm{C}_{1}{ }^{\prime}-\mathrm{H}\right), 7.76(\mathrm{~d}, J=14.2 \mathrm{~Hz}, 1 \mathrm{H}$, $\left.\mathrm{C}_{5}-\mathrm{H}\right), 7.87\left(\mathrm{dd}, J=76.5,10.3 \mathrm{~Hz}, 1 \mathrm{H}, \mathrm{C}_{2}{ }^{\prime}-\mathrm{H}\right), 8.36(\mathrm{br}, 3 \mathrm{H}$, $\mathrm{NH} \cdot \mathrm{HCl}), 8.49\left(\mathrm{~s}, 1 \mathrm{H}, \mathrm{C}_{2}-\mathrm{H}\right), 15.0(\mathrm{br}, 1 \mathrm{H}, \mathrm{COOH}) . \mathrm{IR}(\mathrm{KBr})$ $\mathrm{cm}^{-1}: 1722,1620$. MS (EI) $\mathrm{m} / z: 365\left(\mathrm{M}^{+}\right)$. HRMS (EI) for $\mathrm{C}_{17} \mathrm{H}_{17} \mathrm{~F}_{2} \mathrm{~N}_{3} \mathrm{O}_{4}\left(\mathrm{M}^{+}\right)$: calcd, 365.1187; found, 365.1214. Anal. $\left(\mathrm{C}_{17} \mathrm{H}_{17} \mathrm{~F}_{2} \mathrm{~N}_{3} \mathrm{O}_{4} \cdot \mathrm{HCl} \cdot 0.75 \mathrm{H}_{2} \mathrm{O}\right) \mathrm{C}, \mathrm{H}, \mathrm{N}$.

In Vitro Antibacterial Activity. The MIC $(\mu \mathrm{g} / \mathrm{mL})$ was determined by the agar dilution method ${ }^{14}$ using MullerHinton agar (Difco Laboratories, Detroit, MI). The MIC was defined as the lowest concentration of an antibacterial agent that inhibited visible growth after incubation at $35{ }^{\circ} \mathrm{C}$ for 18 h. 
Inhibitory Activity against DNA Gyrase of S. aureus. The supercoiling activity of DNA gyrase was determined by a previously reported procedure. ${ }^{15}$ The inhibitory activity was assayed by determining the concentration required to inhibit $50 \%$ of the enzyme reaction.

Acknowledgment. We thank Dr. Keiji Hirai, Kyorin Pharmaceutical Co. Ltd., for his encouragement and support of this project. We are also grateful to Dr. Yasumichi Fukuda, Kyorin Pharmaceutical Co. Ltd., and Drs. James V. Heck and Milton L. Hammond, Merck Research Laboratories, for their close readings of this manuscript and for their helpful comments on the study. We also thank Mr. Masaya Takei and Ms. Hinako Gomori, Kyorin Pharmaceutical Co. Ltd., for providing the antibacterial data.

Supporting Information Available: Purity data for compounds 12-16. This material is available free of charge via the Internet at http://pubs.acs.org.

\section{References}

(1) Koga, H.; Itoh, A.; Murayama, S.; Suzue, S.; Irikura, T. StructureActivity Relationships of Antibacterial 6,7- and 7,8-Disubstituted 1-Alkyl-1,4-dihydro-4-oxoquinolone-3-carboxylic Acids. J. Med. Chem. 1980, 23, 1358-1363.

(2) (a) Wise, R.; Andrews, J. M.; Edwards, L. J. In Vitro Antibacterial Activity of Bay 09867, a New Quinolone Derivative, Compared with Those of Other Antimicrobial Agents. Antimicrob. Agents Chemother. 1983, 23, 559-564. (b) Grohe, K.; Heitzer, H. Cycloaracylation of Enamines, I. Synthesis of 4-Quinolone3-carboxylic Acids. Liebigs Ann. Chem. 1987, 29-37.

(3) (a) Atarashi, S.; Yokohama, S.; Yamamzaki, K.; Sakano, K. Imamura, M.; Hayakawa, I. Synthesis and Antibacterial Activity of Optically Active Ofloxacin and Its Fluoromethyl Derivative. Chem. Pharm. Bull. 1987, 35, 1896-1902. (b) Une, T.; Fujimoto, T.; Sato, K.; Osada, Y. Synthesis and Antibacterial Activity of Optically Active Ofloxacin. Antimicrob. Agents Chemother. 1988, 32, 559-564.

(4) (a) Asahina, Y.; Ishizaki, T.; Suzue, S. Recent advances in structure activity relationships in new quinolones. In Fluorinated Quinolones-New Quinolones Antimicrobials; Mitsuhasi, S., Junker, E., Eds.; Progress in Drug Research, Vol. 38; Birkhauser Verlag: Basel, Switzerland, 1992; pp 57-106. (b) Domagara, J. M. Structure-activity and structure-side-effect relationships for the quinolone antibacterials. J. Antimicrob. Chemother. 1994, 33, 685-706.

(5) Atarashi, S.; Imamura, M.; Kimura, Y.; Yoshida, A.; Hayakawa, I.; Fluorocyclopropyl Quinolones. 1. Synthesis and StructureActivity Relationships of 1-(2-Fluorocyclopropyl)-3-pyridonecarboxylic Acid Antibacterial Agents. J. Med. Chem. 1993, 36, 3444-3448.

(6) Hirai, K.; Aoyama, H.; Hosaka, Y.; Oomori, Y.; Niwata, S.; Suzue, S.; Irikura, T. In Vitro and in Vivo Antibacterial Activity of AM833. A New Quinolone Derivative. Antimicrob. Agents Chemother. 1986, 29, 1059-1066.

(7) (a) Trost, B. M.; Salzmann, T. N.; Hiroi, K. New Synthetic Reactions. Sulfenylation and Dehydrosulfenylations of Esters and Ketones. J. Am. Chem. Soc. 1976, 98, 4887-4902. (b) Reutrakul, V.; Rukachaisirikul, V. Fluoromethyl Phenyl Slofox- ide: Highly Convenient Synthesis of Vinyl Fluoride and Fluoromethylketone. Tetrahedron Lett. 1983, 24, 725-728. (c) Purrington, S. T.; Pittman, J. H. The Preparation of $\alpha$-Fluorosulfoxide and Vinyl Fluoride. Tetrahedron Lett. 1987, 28, 3901-3904. (d) McCathy, J. R.; Jarvi, E. T.; Matthews, D. P.; Edwards, M. L.; Prakash, N. J.; Bowlin, T. L.; Mehdi, S.; Sunkara, P. S.; Bey, P. 4',5'-Unsaturated 5'-Fluoroadenosine Nucleosides: Potent Mechanism-Based Inhibitors of $S$-Adenosyl-L-monocytosine Hydrolase. J. Am. Chem. Soc. 1989, 111, 1127-1128, (e) Allmendinger, T. Ethyl Phenylsulfenyl Fluoroacetare, a New and Versatile Reagent for the Preparation of $\alpha$-Fluoro- $\alpha, \beta$-unsaturated Carboxylic Acid Esters. Tetrahedron 1991, 47, 4905-4914. (f) Robins, M. J.; Wnuk, S. F.; Mullah, K. B.; Dalley, N. K. Nucleic Acid Related Compounds. 80. Synthesis of 5'-S-(Alkyl and aryl)5'-fluoro-5'-thioadenosines with Xenon Difluoride or (Diethylamino)sulfur Trifluoride, Hydrolysis in Aqueous Buffer, and Inhibition of $S$-Adenosyl-L-homocysteine Hydrolase by Derived "Adenosine 5'-Aldehyde" Species. J. Org. Chem. 1994, 59, 544555.

(8) McCarthy, J. R.; Peet, N. P.; LeTourneau, M. E.; Inbasekaran, M. (Diethylamino)sulfur Trifluoride in Organic Synthesis. 2. The Transformation of Sulfoxide to $\alpha$-Fluoro Thioesters. J. Am. Chem. Soc. 1985, 107, 735-737.

(9) Wnuk, S. F.; Robins, M. J. Antimonyl(III) Chloride Exerts Potent Catalysis of the Conversion of Sulfoxide to $\alpha$-Fluoro Thioesters with (Diethylamino)sulfur Trifluoride. J. Org. Chem. 1990, 55 , 4757-4760.

(10) Fujita, M.; Suzuki, M.; Ogata, K.; Ogura, K. Negative Hyperconjugation Does Not Play an Important Role in $\alpha$-Fluoro Sulfides: An Experimental Demonstration. Tetrahedron Lett. 1991, 32, 1463-1466.

(11) (a) Reference 2b. (b) Sanchez, J. P.; Domagara, J. M.; Hagen, S E.; Heifentz, C. L.; Hutt, M. P.; Nichols, J. B. Structure-Activity Relationships of 8-Substituted Quinolone-3-carboxylic Acid and 1,8-Naphthylidine-3-carboxylic Acids. J. Med. Chem. 1988, 31, 983-991. (c) Masuzawa, K.; Suzue, S.; Hirai, K.; Ishizaki, T. Preaparation of 8-Alkoxyquinolonecarbixylic Acids as Antibacterials with Selective Toxicity. EP230295. (d) Sanchez, J. P. Gogliotti, R. D.; Domagara, J. M.; Gracheck, S. J.; Huband, M. D.; Sesnie, J. A.; Cohen, M. A.; Shapiro, M. A. The Synthesis, Structure-Activity, and Structure-Side Effect Relationships of a Series of 8-Alkoxy- and 5-Amino-8-alkoxyquinolone Antibacterial Agents. J. Med. Chem. 1995, 38, 4478-4487.

(12) Todo, Y.; Nitta, J.; Miyazima, M.; Fukuoka, Y.; Yamashiro, Y.; Nishida, N.; Saikawa, I.; Narita, H.; Pyridonecarboxylic Acids as Antibacterial Agents VIII. Synthesis and Structure-Activity Relationships of 7-(1-Aminocyclopropyl)-4-oxo-1,8-naphthylidine3-carbixylic Acids and 7-(1-Aminocyclopropyl)-4-oxoquinoline3-carboxylic Acids. Chem. Pharm. Bull. 1994, 42, 2063-2070.

(13) (a) Domagala, J. M.; Heifentz, C. L.; Hutt, M. P.; Mich, T. F.; Nichols, J. B.; Solomon, M.; Worth, D. F.; 1-Substituted 7-[3[(Ethylamino)methyl]-1-pyrrolidinyl]-6,8-difluoro-1,4-dihydro-4oxo-3-quinolinecarboxylic Acids. New Quantitative StructureActivity Relationships at $\mathrm{N}_{1}$ for the Quinolone Antibacterials. J. Med. Chem. 1988, 31, 991-1001. (b) Ohta, M.; Koga, H. ThreeDimensional Structure-Activity Relationships and Receptor Mapping of N1-Substituents of Quinolone Antibacterials. J. Med. Chem. 1991, 34, 131-139.

(14) Japan Society of Chemotherapy. Chemotherapy 1981, 29, 76.

(15) Takei, M.; Fukuda, H.; Kishii, R.; Hosaka, M.; Target Preference of 15 Quinolones against Staphylococcus aureus, Based on Antibacterial Activities and Target Inhibition. Antimicrob. Agents Chemother. 2001, 45, 3544-3547. 